\title{
DISTINGUISHING CHARTER RIGHTS IN \\ CRIMINAL AND REGULATORY INVESTIGATIONS: What's The Purpose of ANALYZING Purpose?
}

\author{
CHRISTOPHER SHERRIN*
}

This article critically evaluates one of the main justifications for affording persons accused of regulatory offences constitutional protections different from those afforded to persons accused of criminal offences. It is only the latter who enjoy robust constitutional protection against self-incrimination and to privacy. This difference has been justified on the basis that there are different purposes behind regulatory and criminal investigations. The former are supposedly intended to ensure compliance with the law whereas the latter are supposedly intended to gather evidence for prosecution. This article challenges the validity of the justification based on purpose. The author suggests that focusing on investigatory purpose has no relevance to the interests protected by the right to privacy, offers no real protection against the admission of unreliable evidence, and undermines the very principle it is said to protect: the principle against self-incrimination. Moreover, the justification based on purpose misunderstands the purposes of both regulatory and criminal investigations and ignores the reality that in many instances they share the same purpose.
Cet article critique sévèrement une des grandes justifications pour lesquelles les personnes accusées d'infractions réglementaires reçoivent des protections constitutionnelles différentes de celles accordées aux personnes accusées d'infractions criminelles. C'est uniquement la dernière catégorie qui obtient une solide protection constitutionnelle contre l'autoincrimination et la protection de la vie privée. La différence se justifie sur la base que les enquêtes réglementaires et criminelles ont des raisons d'être différentes. La première catégorie vise normalement à assurer le respect de la loi alors que la seconde vise normalement à accumuler la preuve en vue de poursuites. Cet article remet en question la validité de la justification fondée sur la raison d'être. L'auteur suggère que le fait de cibler la raison d'être de l'enquête n'est pas pertinent aux intérêts protégés par le droit à la vie privée, qu'elle ne donne aucune protection véritable contre l'acceptation de preuve peu fiable et sape le principe même qu'elle devrait protéger, notamment le principe contre l'autoincrimination. De plus, la justification est basée sur la raison d'être comprend mal l'objectif des enquêtes réglementaires et criminelles et ignore la réalité que dans bien des cas, elles ont la même raison d'être.

\section{TABLE OF CONTENTS}

I. INTRODUCTION . . . . . . . . . . . . . . . . . . . . 94

II. The CRIMINAL/REgULATORY DistinCTION . . . . . . . . . . . . . . . . . . 95

A. The Right Against SELF-InCRiminAtion . . . . . . . . . . . . 96

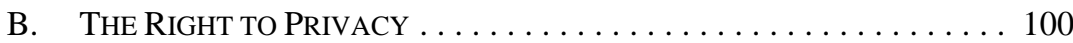

III. JUSTIFYING THE DiSTINCTION $\ldots \ldots \ldots \ldots \ldots \ldots \ldots \ldots \ldots \ldots \ldots \ldots \ldots \ldots$

IV. Evaluating the Purpose Argument $\ldots \ldots \ldots \ldots \ldots \ldots \ldots \ldots \ldots$

A. FILLING IN THE ARgUMENT $\ldots \ldots \ldots \ldots \ldots \ldots \ldots \ldots$

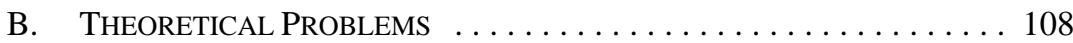

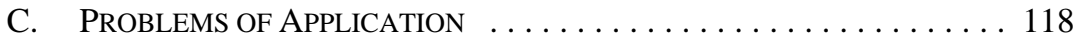

V. CONCLUSION . . . . . . . . . . . . . . . . . . . . . . . . . . . . . . 124

Faculty of Law, University of Western Ontario. Thanks to Don Stuart, Kent Roach, and Paul Emond for their comments on earlier versions of the article. 


\section{INTRODUCTION}

A much litigated issue in Canadian law has been the extent to which the protections afforded by the Canadian Charter of Rights and Freedoms ${ }^{1}$ in criminal investigations should also be afforded in regulatory investigations. Targets of criminal investigations have a variety of constitutional rights that have the effect of limiting the power of state authorities to gather evidence of wrongdoing. Most importantly for present purposes, they have constitutional rights against self-incrimination and to privacy. As a result, they cannot be compelled by law to provide pre-trial statements to police that can later be used against them at trial, and the police generally cannot, without warrant, invade their privacy to search for and seize incriminating evidence.

Targets of regulatory investigations cannot say the same thing. Regulatory investigations relate to the enforcement of regulatory statutes, such as tax acts, environmental acts, and occupational health and safety acts. ${ }^{2}$ They sometimes result in prosecutions for breaches of those acts (that is, for regulatory offences). ${ }^{3}$ For example, enforcement of the federal Fisheries Act $t^{4}$ may result in a prosecution for overfishing. ${ }^{5}$ Persons accused of such offences have often sought constitutional protection similar to that afforded to criminal accused. But, as the law now stands, in many cases the targets of regulatory investigations can be statutorily compelled to provide pre-trial statements that can later be used against them at trial, and regulatory investigators can, without warrant or even grounds to believe that an offence has occurred, invade their privacy and search for and seize incriminating evidence. ${ }^{6}$

Part I of the Constitution Act, 1982, being Schedule B to the Canada Act 1982 (U.K.), 1982, c. 11 [Charter].

$2 \quad$ As this suggests, by "investigation" I refer loosely to the acts of a public authority in seeking to enforce a law. In the regulatory context courts sometimes use the term more narrowly. An investigation is said to occur when the public authority is trying to gather evidence in support of an allegation of wrongdoing. When the public authority is only seeking to monitor general compliance with the law without the specific or predominant purpose of collecting incriminating evidence, she is said to be engaging in an inspection or an audit (or some similar term), not an investigation. Unfortunately, there is no neutral term that refers generically to acts of enforcement by public authorities, so I have to choose one of investigation, inspection, audit, etc. Since the distinction being drawn between the terms is the very distinction that I criticize in this article - one based on purpose - I choose investigation. Regulatory offences go by various names: public welfare offences, administrative offences, civil crimes, petty infractions, etc. For the most part, they all refer to the same general type of illicit conduct and thus I employ the single term "regulatory offence" here. It is the term most commonly used in Canadian jurisprudence. Regulatory offences have been variously defined as infractions "created by statutes enacted for the regulation of individual conduct in the interests of health, convenience, safety and the general welfare of the public" and as "conduct, otherwise lawful, which is prohibited in the public interest”: see R. v. Pierce Fisheries Ltd. (1970), [1971] S.C.R. 5 at 13 and R.v. Wholesale Travel Group Inc., [1991] 3 S.C.R. 154 at 216 [Wholesale Travel], respectively. They are distinguished from criminal offences and, sometimes, quasi-criminal offences: see e.g. Thomson Newspapers Ltd. v. Canada (Director of Investigation and Research, Restrictive Trade Practices Commission), [1990] 1 S.C.R. 425 [Thomson Newspapers]. Into which category a particular offence falls is not always clear, and one must resort to case law for guidance.

$4 \quad$ R.S.C. 1985 , c. F-14.

See R. v. Fitzpatrick, [1995] 4 S.C.R. 154 [Fitzpatrick] (technically, the offence is catching and retaining fish in excess of quota). Other examples of regulatory offences include discharging a contaminant into the environment contrary to the Ontario Environmental Protection Act, R.S.O. 1990, c. E-19, s. 14, and hunting within a quarter-mile of bait contrary to the Migratory Birds Convention Act, 1994, S.C. 1994, c. 22: see R. v. Weil's Food Processing Ltd. (1990), 6 C.E.L.R. (N.S.) 249 (Ont. Ct. J. (Gen. Div.)); R. v. Chapin, [1979] 2 S.C.R. 121. Regulatory offences are mostly found in provincial legislation and federal laws other than the Criminal Code, R.S.C. 1985, c. C-46.

6 As with the term investigation, I am using the term "search" broadly to refer to any state action involving intrusion and examination. I am not using it to refer to intrusions with any particular purpose (such as the discovery of incriminating evidence) or to distinguish it from the term inspection. 
Many reasons have been advanced to justify this differential treatment, but arguably the leading one is based on investigatory purpose. It is alleged that the purposes of regulatory and criminal investigations differ. Regulatory investigations are intended to ensure compliance with the law. The goal is to educate, correct problems, and prevent recurrence. Prosecution is not of primary concern. By contrast, in criminal investigations prosecution is of primary concern. The goal is to detect offences, gather evidence, and punish offenders. Compliance is a desirable but merely incidental consequence. It is this prosecutorial purpose for criminal investigations that is alleged to justify enhanced constitutional protection against compelled speech and warrantless intrusions. Failure to provide that protection would violate the principle against self-incrimination.

Probably the most important example of this reasoning is found in the Supreme Court of Canada's decision in R. v. Jarvis, ${ }^{7}$ but many other examples can be found. Indeed, the reasoning has been applied in a multitude of cases and contexts to justify differential constitutional treatment of criminal and regulatory accused. In my view, however, the reasoning is flawed. It offers no valid basis for distinguishing between rights in criminal and regulatory investigations. The reasoning has no relevance to the constitutional right to privacy, undermines the principle against self-incrimination, offers no real protection against the admission of unreliable evidence, and mischaracterizes the true nature of regulatory and criminal enforcement. At best, the reasoning could be used to distinguish Charter rights in some situations but it would probably be wisest to look for more defensible grounds for determining when someone should be compelled to provide an admissible statement to the authorities, and when the authorities should be entitled to intrude upon private areas absent prior judicial authorization.

This article is divided into four parts. In Part II, I outline how the law provides different constitutional protection to the targets of regulatory versus criminal investigations. In Part III, I demonstrate how courts and commentators have sought to justify that difference by reference to the argument based on investigatory purpose. In Part IV, I criticize that argument. I first explain why a focus on investigatory purpose is misplaced: it does not safeguard the fairness of a trial or protect against the admission of unreliable evidence. I then explain why, in any event, the argument based on purpose does not justify a constitutional distinction between criminal and regulatory investigations. Much criminal enforcement shares the same purpose as regulatory enforcement. Both are frequently undertaken as a means of securing compliance rather than pursuing prosecution.

\section{The Criminal/Regulatory Distinction}

It is rarely easy to briefly summarize principles of constitutional law, and summarizing the law as it relates to the rights against self-incrimination and to privacy is no exception. But, as a general statement, it is accurate to say that in criminal investigations, unlike in regulatory investigations, a person cannot be compelled by law to give statements to the investigating authorities that can later be used against her in a prosecution for an offence, and cannot usually be subjected to warrantless state intrusions on her privacy. 


\section{A. The Right Against Self-InCRimination}

At first blush, it may seem odd to ask about compelled self-incrimination in criminal law. Nothing in the Criminal Code requires a person to make a statement to the police that could later be used against her at trial. ${ }^{8}$ However, the issue has arisen in criminal law in one context: when the enforcement of a criminal law has intersected with the enforcement of a regulatory law.

There are many regulatory statutes that require individuals to speak, in one way or another, to public authorities charged with enforcing regulatory laws. The Canadian Environmental Protection Act, 1999, for example, requires the owner or person in charge of a place subject to inspection or court-authorized search, and every person found in the place, to provide an enforcement officer with any information respecting the administration of the Act that the officer may reasonably require. ${ }^{9}$ The federal Fisheries Act requires people engaged in the fishing industry to keep records relating to their activities and to turn the records over to fisheries authorities upon request. ${ }^{10}$ The Ontario Water Resources Act obliges every person who discharges or permits the discharge of any material that may impair water quality to immediately notify the Minister of the Environment of the discharge. ${ }^{11}$ Many other examples could be listed, but the point is that people are often obliged by law to make statements to the authorities. Most of those statements are of no interest to the police investigating crimes, but some of them are. And in some situations the prosecution will seek to tender a compelled statement against its maker at trial.

One such situation arose in the case of $R$. v. White. ${ }^{12}$ Ms. White was charged with failing to stop at the scene of an accident, contrary to the Criminal Code. The applicable provincial motor vehicle Act required drivers involved in accidents to report the facts of the accident to the police. White did so and the prosecution sought to introduce her statements at her criminal trial. The case went all the way up to the Supreme Court of Canada. The issue was whether the Charter granted White any protection against the use of her statements.

The Court ultimately ruled the statements inadmissible on the basis that admission would violate the principle against self-incrimination protected by s. 7 of the Charter. This obviously suggests that the state cannot compel a person to talk and then use the statement against her in a criminal prosecution. But one must be cautious about taking too much from the decision in White. Despite its ultimate holding, the Court actually stated that the principle against self-incrimination “does not imply ... absolute protection for an accused against all uses of information that has been compelled by statute or otherwise."13 The Court also concluded that the statements at bar were inadmissible only after balancing several factors:

Section 83.28 of the Criminal Code, supra note 5, contains an obligation to speak in the context of a terrorism investigation, but it grants both use and derivative use immunity in any subsequent criminal proceeding. The Criminal Code (like many other statutes) can be used to compel a person to testify before a court or other tribunal, but s. 13 of the Charter prevents the Crown from using the person's testimony against her in a later criminal or regulatory prosecution: see R. v. Henry, 2005 SCC 76, [2005] 3 S.C.R. 609 [Henry].

S.C. 1999, c. 33, s. 227 [CEPA].

Supra note 4, s. 61.

R.S.O. 1990, c. O-40, s. 30(2).

[1999] 2 S.C.R. 417 [White].

Ibid. at para. 45. 
the coercion involved in obtaining the statements, the existence of an adversarial relationship between the accused and the state at the time the statements were obtained, the risk of unreliable confessions as a result of the statutory compulsion, and the risk of abuses of state power as a result of the statutory compulsion. ${ }^{14}$ We do not know if, in fact situations different from those in White, balancing these factors might lead to a different result.

That said, it is actually extremely unlikely that the courts will often balance the factors in such a way as to lead to admissibility. Experience tells us otherwise. Courts thus far have routinely held, in a variety of situations, that compelled statements were not admissible in criminal trials. ${ }^{15}$ Indeed, some have seen the holding as almost automatic. ${ }^{16}$ This is not technically correct, of course, but it reflects a common attitude. ${ }^{17}$ The practical effect of White, therefore, seems to be that compelled statements are not admissible in criminal trials.

Matters have worked out quite differently for those accused of regulatory offences. The constitutionality of admitting statutorily compelled statements against them was considered in Fitzpatrick. ${ }^{18}$

Brendon Fitzpatrick was charged with catching fish in excess of quota contrary to a regulation of the Fisheries Act. To prove the amount of fish caught, the prosecution sought to rely upon two reports filed by Fitzpatrick pursuant to his legal obligations under the Act. The reports listed the location, date, and estimated amount of his catch. The defence objected that they were self-incriminatory and that their admission would infringe Fitzpatrick's rights under s. 7 of the Charter.

In a unanimous decision, the Supreme Court of Canada held that the reports were admissible (for the truth of their contents). The Court stated that the Charter does not always preclude the use of statutorily compelled information and in the context of the case, "which involve[d] a self-reporting requirement in the regulatory sphere," 19 no breach was established.

The presence of one or more of these factors argues for exclusion, their absence for admission. In White, ibid., the Court found (generally in the abstract) that the relationship between driver and police officer is adversarial since the officer is investigating a possible crime at the same time as taking the accident report; that there is a risk of a false statement because a motorist may fear the consequences of telling the truth; that the police officer might abuse his power by overemphasizing the extent of the statutory duty (in order to obtain inculpatory information); and that coercion is a neutral factor since people choose to drive but not with the same freedom that people make other choices.

See e.g. R. v. DaCosta (2001), 156 C.C.C. (3d) 520 (Ont. Sup. Ct. J.) (compulsion under the Compulsory Automobile Insurance Act, R.S.O. 1990, c. C-25); R. v. Jones, [2002] O.J. No. 2136 (Sup. Ct. J.) (QL) (compulsion under the Coroners Act, R.S.O. 1990, c. C-37); R. v. Wighton (2003), 176 C.C.C. (3d) 550 (Ont. Sup. Ct. J.) (compulsion under the Police Services Act, R.S.O. 1990, c. P-15); R. v. Aziga, [2006] O.J. No. 5232 (Sup. Ct. J.) (QL) [Aziga] (compulsion under the Health Protection and Promotion Act, R.S.O. 1990, c. H-7); R. v. Choy, 2008 ABQB 737, 456 A.R. 215 [Choy] (compulsion under the Residential Facilities Licensing Regulation, Alta. Reg. 161/2004). For a rare exception, see R. v. Barnes, [2007] O.J. No. 1224 (Sup. Ct. J.) (QL) [Barnes].

16 The Newfoundland Supreme Court in R. v. Leyte, 2004 NLSCTD 177, 240 Nfld \& P.E.I.R. 158 at para. 35, for example, said that if a statement "was taken on the understanding that this was something [the accused] had to give under the Highway Traffic Act, the statement has use immunity. This means that the statement cannot be used in a criminal proceeding. The case law is quite clear on this point.”

17 See also R. v. Armstrong, 2008 BCSC 1693, [2008] B.C.J. No. 2583 at paras. 2, 15 (QL) [Armstrong]; R. v. Powers, 2006 BCCA 454, 213 C.C.C. (3d) 351 at paras. 9-17 [Powers]; R. v. Thomas, 2003 MBQB 280, 183 Man. R. (2d) 6 at paras. 27-30; R. v. Donovan (2001), 83 C.R.R. (2d) 172 at 177 (Ont. Sup. Ct. J.); R. v. Colquhoun, [2002] O.J. No. 349 at para. 1 (Ct. J.) (QL). 
The Supreme Court did not rule that statutorily compelled statements were always admissible at regulatory trials. It came to its conclusion after considering several factors in the context of the proceedings at bar: the presence of an adversarial relationship, the level of state coercion, the risk of a false confession, and the risk of the abuse of state power. ${ }^{20}$ These, of course, were the same factors that the Court considered anew in White and, as with criminal proceedings, these factors might be balanced so as to lead to a different result in another regulatory prosecution. Arguably, in fact, this has already happened. ${ }^{21}$ However, the large majority of cases have applied Fitzpatrick with the same result, even when the statement was compelled for the specific purpose of investigating a regulatory offence. ${ }^{22}$ This is not surprising given the critical importance placed upon the regulatory context throughout the Fitzpatrick reasons. The Supreme Court repeatedly stressed the fact that the offence and legislation in question were regulatory and not criminal. ${ }^{23}$ Lower courts cannot help but receive the message that the rule prohibiting compelled self-incrimination in criminal proceedings does not normally apply to regulatory proceedings. ${ }^{24}$

A consideration of White and Fitzpatrick, therefore, clearly leads to the conclusion that the constitutional rules are different for criminal and regulatory accused. The state can really only use the compelled statements of the latter at trial. One cannot come to any final conclusions, however, without considering the Supreme Court's decisions in Jarvis ${ }^{25}$ and $R$. v. Ling. $^{26}$

Mr. Jarvis was charged with offences relating to tax evasion (which the Court treated as criminal in nature). Evidence of the offences was obtained during the course of an audit of his tax returns. During the course of her review, the auditor relied upon provisions of the Income Tax $\mathrm{Act}^{27}$ that grant auditors access to taxpayer records and require taxpayers to answer relevant questions. Jarvis was in fact questioned by the auditor. His answers were later used to help obtain a search warrant for records, which the Crown sought to introduce

Ibid. In brief, the Court found that there was no adversarial relationship at the time the records were filed with the government (at paras. 35-36), that the coercion exercised by the state was muted in light of Fitzpatrick's voluntary decision to participate in the fishery (at para. 42), that the absence of use immunity did not increase the chances of false confession, and that it was not abusive to prosecute overfishing on the basis of true returns that the state requires fishers to fill out as a condition of their voluntary participation in the commercial fishery (at paras. 46-47).

See R. v. Zalai, [2000] O.J. No. 3294 (Ct. J.) (QL); R. v. Faruq, 2003 BCPC 340, 113 C.R.R. (2d) 1 [Faruq]. It may be possible to interpret both cases as an application of the factors in a quasi-criminal situation as opposed to a regulatory one. Note as well that the Court in Faruq ultimately admitted the statements under s. 24(1) of the Charter.

22 See e.g. R. v. Ginetz, 2005 BCPC 195, [2005] B.C.J. No. 1169 (QL) [Ginetz]; R. v. Balogh (2003), 109 C.R.R. (2d) 303 (Ont. Ct. J.) [Balogh]; R. v. Visuvalingam, [2002] O.J. No. 3515 (Ct. J.) (QL); R. v. 952133 Ontario (2000), 73 C.R.R. (2d) 183 (Ont. Ct. J.) [952133 Ontario]; R. v. Valshanov, [2000] N.J. No. 30 (S.C. (T.D.)) (QL); R. v. Czaplinski, [1999] O.J. No. 5036 (Ct. J.) (QL); R. v. Pe Ben Industries, 1999 ABQB 363, 246 A.R. 50.

23 See supra note 5 at paras. 22-32, 38-40, 52-55.

24 The Court in 952133 Ontario, supra note 22, for example, held at 186 that

[t]he Supreme Court of Canada in R. v. Fitzpatrick ... clearly established that, in the context of regulatory schemes, mandatory reporting conditions required of licensees which are subsequently used by the Crown for enforcement do not violate any s. 7 interest against self-incrimination.... The jurisprudence relating to $\mathrm{s}$. 7 of the Charter which prohibits the admission of statements made by an accused as a result of statutory compulsion applies to criminal proceedings.... Section 7 Charter protections in a criminal context are clearly distinguishable from regulatory enforcement procedures such as the matter before this court and, based on $R$. v. Fitzpatrick ... do not extend to these proceedings.

Supra note 7.

2002 SCC 74, [2002] 3 S.C.R. 814 [Ling].

R.S.C. 1985 (5th Supp.), c. 1. 
at trial. Jarvis applied to exclude the seized records, arguing that use of, inter alia, his compelled statements to further the tax evasion investigation violated his rights under the Charter. In the companion case of Ling, the Supreme Court was faced with a very similar fact situation except that, in Mr. Ling's case, the prosecution sought to introduce the compelled statements themselves at trial.

The Court concluded that the statements were admissible (or, in the case of Jarvis, usable). They were admissible because they were compelled for the purposes of the administration or enforcement of the Income Tax Act, a regulatory law. It is only when statements are compelled "for the predominant purpose of determining penal liability" 28 that they are inadmissible because it is only then that an adversarial relationship exists between the state and the individual. ${ }^{29}$ In the Court's words, the powers in the Income Tax Act "cannot be used to compel oral statements ... for the purpose of advancing [a] criminal investigation." 30

Jarvis and Ling seem to significantly alter the law based on White and Fitzpatrick. ${ }^{31}$ Jarvis and Ling suggest that admissibility of compelled statements is dependent on one factor: the presence or absence of an adversarial relationship (which is determined by the state's predominant purpose). White and Fitzpatrick, on the other hand, state that admissibility is dependent on four factors, only one of which is the presence or absence of an adversarial relationship. Even though Jarvis and Ling were criminal cases, this change presumably impacts Fitzpatrick as much as White. White adopted and applied the reasoning of Fitzpatrick, so any impact of Jarvis and Ling on White redounds to the application of Fitzpatrick. The bottom line after Jarvis and Ling, therefore, may be that compelled statements are sometimes admissible in criminal trials - namely, where they were compelled for regulatory purposes and not for the predominant purpose of determining penal liability ${ }^{32}$ — and, conversely, that compelled statements are sometimes inadmissible in regulatory trials - namely, where they were compelled for the predominant purpose of determining penal liability. ${ }^{33}$

The law in practice, however, seems to be different. Courts subsequent to Jarvis and Ling have not treated the cases as determinative. In considering the admissibility of compelled statements in both criminal and regulatory trials, courts have usually ignored Jarvis and Ling and only considered Fitzpatrick and/or White (with typical results), ${ }^{34}$ although they have

$28 \quad$ Ling, supra note 26 at para. 7.

$29 \quad$ See Jarvis, supra note 7 at para. 88; Ling, ibid. at paras. 1-6.

$30 \quad$ Jarvis, ibid. at para. 97

31 This impact is only implicit because the Court in Jarvis and Ling did not discuss or consider White and Fitzpatrick at any length. It cited them for a few relatively innocuous propositions, but otherwise ignored them.

32 One cannot forget that regulatory officials commonly gather information for purposes that have nothing to do with penalizing anyone, such as the setting of fishing quotas, the assessment of tax owing, or the revocation or alteration of licences.

33 This latter suggestion assumes that "penal liability" includes liability for regulatory offences, an assumption that many courts have made: see e.g. United States v. Asiegbu, 2007 BCSC 96, [2007] B.C.J. No. 107 at para. 14 (QL); R. v. Kooktook, 2006 NUCA 3, 391 A.R. 1 at paras. 85-89 [Kooktook]; R. v. Canada Brick Ltd., [2005] O.J. No. 2978 at para. 162 (Sup. Ct. J.) (QL) [Canada Brick].

$34 \quad$ See e.g. Choy, supra note 15; Armstrong, supra note 17; R. v. Hayes, [2003] O.J. No. 4590 (C.A.) (QL); R. v. Zwicker, 2003 NSCA 140, 186 C.C.C. (3d) 395, leave to appeal to S.C.C. refused (2004), [2004] 3 S.C.R. xii [Zwicker]; Powers, supra note 17; Balogh, supra note 22; Aziga, supra note 15; Ginetz, supra note 22; Barnes, supra note 15; R. c. Coté, 2006 QCCQ 13381, [2006] J.Q. no 14437 (QL); $R$. v. Etienne, 2005 BCPC 98, 129 C.R.R. (2d) 34; R. v. Walker, [2005] O.J. No. 6159 (Sup. Ct. J.) (QL); 
sometimes ignored Fitzpatrick and/or White and only considered Jarvis, ${ }^{35}$ applied all three cases serially, ${ }^{36}$ or sought (in an unhelpful way) to distinguish Jarvis and Ling $^{37}$ or Fitzpatrick. ${ }^{38}$ As the law has developed, therefore, Jarvis and Ling do not seem to have significantly changed the impact of White and Fitzpatrick. ${ }^{39}$ At least outside of the tax context, the state seems to be only able to use compelled statements against those accused of regulatory offences.

To the extent that Jarvis and Ling apply, one still comes to the same conclusion. Jarvis held that statutory powers cannot be used to compel oral statements for the purpose of advancing a criminal investigation. Thus, it seems that Parliament could not, if it was so inclined, amend the Criminal Code to compel admissible statements from the targets of criminal investigations. ${ }^{40}$ At most, the authorities can occasionally rely on statutory compulsions contained in regulatory statutes. But since most criminal investigations are unconnected with the administration of a regulatory statute, most of the time admissibility under Jarvis and Ling will not be available. On the other hand, since most regulatory investigations are connected with the administration of a regulatory statute, admissibility under Jarvis and Ling will be available. Thus, as a practical matter, on any reading of the law criminal accused have a broader right against self-incrimination than regulatory accused.

\section{B. The Right to Privacy}

As a rule, the Charter dictates that investigators in criminal matters may not undertake searches or seizures, absent consent, ${ }^{41}$ without prior judicial authorization. ${ }^{42}$ In other words,

R. v. MacKay, 2008 NSPC 8, 263 N.S.R. (2d) 207; R. v. Lynch, 2008 ABQB 506, 453 A.R. 186. It seems quite likely that, in at least some of these cases, the application of the Jarvis predominant purpose test would have led to a different result. 35 This is routine in tax cases: see e.g. $R$. v. Anderson, 2003 SKCA 27, 232 Sask. R. 250; R. v. Bjellebo
(2003), 177 O.A.C. 378, leave to appeal to S.C.C. refused (2004), 330 N.R. 398 (note). It also happens occasionally in non-tax cases: see e.g. R. v. Rice, 2007 BCSC 1828, [2007] B.C.J. No. 2699 (QL) [Rice]. The Court in Rice mentioned Fitzpatrick and White, but only to the extent of asserting that Ling reflected those decisions.

$36 \quad$ R. v. Jones, [2004] O.J. No. 1741 (Sup. Ct. J.) (QL), aff'd on other grounds (2006), 81 O.R. (3d) 481 (C.A.).

37 R. v. Douglas, 2002 BCPC 666, [2002] B.C.J. No. 3134 (QL); Faruq, supra note 21. In the former case, the distinction was made on the spurious ground that Ling only addressed the admissibility of documents, not statements. In the latter case, the distinction was made on the ground that the state authorities involved were the police rather than tax auditors, and as a result there was no blurring of regulatory and penal roles.

$38 \quad$ Kooktook, supra note 33. The Court held that Fitzpatrick did not apply because the accused was not participating in a commercial fishing industry.

39 At times, it seems like the courts are treating Jarvis and Ling as relevant only to warrantless inspections and demands for productions and not to statutorily compelled statements, even though that is clearly erroneous. In both cases it is beyond question that both compelled documents and statements were at issue.

$40 \quad$ See also Re Application under s. 83.28 of the Criminal Code, 2004 SCC 42, [2004] 2 S.C.R. 248 at paras. 70-71:

This Court has recognized that the right against self-incrimination is a principle of fundamental

justice.... [T] ]he more recent jurisprudence of our Court on self-incrimination developed such that three procedural safeguards emerged: use immunity, derivative use immunity, and constitutional exemption.... Together these necessary safeguards provide the parameters within which selfincriminating testimony may be obtained.

The Court was speaking of the criminal context.

$41 \quad$ R. v. Wills (1992), 7 O.R. (3d) 337 at 348-49 (C.A.).

42 Hunter v. Southam Inc., [1984] 2 S.C.R. 145 at 160-61 [Hunter]. 
they first need to get a warrant. ${ }^{43}$ This rule applies even if a seizure is made absent any accompanying search (as in the case of a demand for production). ${ }^{44}$

Normally, a warrant can only be granted based on information, established upon oath, that demonstrates reasonable grounds to believe an offence has been committed and that there is evidence to be found at the place of the search or seizure. ${ }^{45}$ Exceptionally, warrants may be authorized based on "reasonable grounds to suspect"; ${ }^{46}$ a threshold that is lower than reasonable grounds to believe but higher than mere suspicion. ${ }^{47}$ Intrusions may not be authorized on the basis of suspicion alone (or less). ${ }^{48}$

These are the basic rules in criminal investigations. As with all rules, there are exceptions. For instance, some warrantless searches can be made upon arrest, ${ }^{49}$ and warrantless seizures can be made of items in plain view. ${ }^{50}$ Evidence obtained from a warrantless intrusion is also sometimes admissible in criminal proceedings when the intrusion was authorized by, and executed for the administration of, a regulatory statute. ${ }^{51}$ These exceptions, although significant, do not swallow the rule. In most circumstances warrantless criminal searches and seizures are unconstitutional. ${ }^{52}$

Regulatory statutes routinely grant state officials the power to search and seize without a warrant. The federal Fisheries Act, for example, empowers fisheries officials, "for the purpose of ensuring compliance" with the Act, to "enter and inspect any place ... in which the officer ... believes on reasonable grounds there is any work or undertaking or any fish or other thing in respect of which this Act or the regulations apply." 53 No warrant is required. No grounds for believing that an offence has occurred are required. The official need only have grounds to believe that there is something in the place to which the Act applies. After the fisheries official has entered a place, the Act empowers her to scrutinize its contents. ${ }^{54}$ If the official finds anything that she reasonably believes "was obtained by or used in ... or will afford evidence of the commission of an offence under [the] Act," she is empowered to seize it. $^{55}$

Regulatory officials can also seize information other than during the course of inspections. Commonly, they can also demand that persons subject to regulation simply turn over

The courts have found statutory grants of warrantless search powers in criminal law to be unconstitutional (other than in cases of exigency): see R. v. Noble (1984), 48 O.R. (2d) 643 (C.A.); $R$. v. Grant, [1993] 3 S.C.R. 223 [Grant]. Hunter, supra note 42 at $165-68$. The information establishing the requisite grounds cannot have been obtained through an unconstitutional search: Grant, supra note 43.

See e.g. Criminal Code, supra note 5, ss. 492.1-492.2.

R. v. Granston (2000), 134 O.A.C. 87 at para. 36.

Hunter, supra note 42 at $166-67$.

See e.g. Cloutier v. Langlois, [1990] 1 S.C.R. 158; R. v. Caslake, [1998] 1 S.C.R. 51; R. v. Golden, 2001 SCC 83, [2001] 3 S.C.R. 679.

The state official must be lawfully entitled to be in the position to view the item: see R. v. Spindloe, 2001 SKCA 58, 207 Sask. R. 3; R. v. Buhay, 2003 SCC 30, [2003] 1 S.C.R. 631.

Jarvis, supra note 7; R. v. Nolet, 2009 SKCA 8, 320 Sask. R. 179; R. v. Diep, 2005 ABCA 54, 363 A.R. 321 [Diep]. The precise breadth and applicability of this exception is not clear.

The Supreme Court has indicated that departures from the Hunter standards will be "exceedingly rare": R. v. Simmons, [1988] 2 S.C.R. 495 at para. 47.

Supra note 4, s. 49(1).

Ibid. Additional powers are granted in s. 49(1.1).

Ibid., s. 51. 
information or records upon request. Thus, for example, CEPA entitles the Minister of the Environment to require any person to produce any documents or data that an enforcement officer reasonably believes "contain ... information relevant to the administration of [the] Act." ${ }^{56}$ It is an offence not to comply ${ }^{57}$ or to provide false or misleading information. ${ }^{58}$

To date, both warrantless demand for production and warrantless inspection powers in regulatory statutes have generally passed constitutional muster. Warrantless demands for production have been considered in a number of cases, including several at the Supreme Court of Canada. Before 2002, such demands had almost always been held not to violate s. 8 of the Charter, even when no protection was afforded against admission of the seized documents in a subsequent prosecution. ${ }^{59}$ As was the case with the right against selfincrimination, the decision in Jarvis complicates matters, ${ }^{60}$ but does not undo the difference between criminal and regulatory law.

Jarvis was not just (or even primarily) about compelled statements. It was also about warrantless intrusions. The Supreme Court held that investigators can demand production without a warrant when the predominant purpose of the demand is not the determination of penal liability, but that they need a warrant when the predominant purpose of the demand is the determination of penal liability. Jarvis, therefore, appears to add a caveat to the earlier rulings regarding demands for production. ${ }^{61}$ But the decision does not alter the assumption that warrantless demands for production are constitutional in regulatory investigations; it just places a limit on the applicability of that assumption. In criminal investigations, by contrast, the assumption is that warrantless demands for production are unconstitutional.

Inspection powers have been considered in a multitude of cases. The great majority of them have upheld the authority of state officials, in the regulatory context, to invade private areas without prior judicial authorization and without grounds to believe or even suspect that an offence has occurred. Although it is difficult to sum up all of the cases briefly, broadly speaking they can be categorized as follows.

Most cases hold that state officials can make use of warrantless inspection powers only as long as their (primary) purpose is not to investigate a suspected offence. ${ }^{62}$ These cases usually reflect and apply the Supreme Court's holding in Jarvis, but some came earlier. ${ }^{63}$ Other cases hold that state officials can employ warrantless inspection powers up to the point that, objectively, they have reasonable grounds to believe an offence has occurred, at which

Supra note 9, ss. 218(10)(c), 219(1).

Ibid., ss. 219(2), 272(1).

Ibid., s. 273.

McKinlay Transport, supra note 44; British Columbia Securities Commission v. Branch, [1995] 2 S.C.R.

3 [Branch]; Thomson Newspapers, supra note 3.

60 The decision in Ling similarly complicates matters, but in the context of search and seizure it adds nothing of significance to the analysis in Jarvis (at least not for present purposes).

$61 \quad$ For recent illustrations of this, see Kooktook, supra note 33; R. v. Landen, 2007 ONCJ 531, [2007] O.J. No. 4445 (QL).

62 R. v. Labrador Sea Products, 2008 NLTD 167, 284 Nfld. \& P.E.I.R. 240 [Labrador Sea Products]; $R$ v. Lowe (2007), 280 Nfld. \& P.E.I.R. 331 (Nfld. Prov. Ct.); R. v. Romano, 2003 SKPC 46, 231 Sask. R. 123 [Romano]; R. v. Milligan, 2004 NSPC 9, 221 N.S.R. (2d) 84 [Milligan]; Canada Brick, supra note 33; Québec (Procureur Général) c. 3766063 Canada, 2007 QCCQ 170, [2007] J.Q. no 269 (QL); R. v. Campbell, 2005 BCPC 713, [2005] B.C.J. No. 3160 (QL).

63 See e.g. R. v. Hillier (1996), 141 Nfld. \& P.E.I.R. 6 (Nfld. Prov. Ct.). 
point they must obtain a warrant before intruding. ${ }^{64}$ Still other cases suggest, without apparent limitation, that the use of a particular inspection power is constitutional (and, by implication, that the use of similar powers generally is constitutional). In other words, the cases uphold a power without suggesting that there may be, in some circumstances, a need to obtain a warrant. ${ }^{65}$

Whatever the reasoning, the result is always the same: in many circumstances state officials can employ warrantless inspection powers and introduce any incriminating evidence found during the inspection at a later regulatory trial. This is not to say that there have not been any constraints placed on the use of inspection powers. Some courts have held that they must be exercised in a reasonable and non-harassing manner. ${ }^{66}$ A couple have held that they cannot be employed absent reasonable grounds to believe that the place to be inspected has some connection with the regulated industry ${ }^{67}$ (although in one case the Supreme Court held differently). ${ }^{68}$ Some have been reluctant to countenance their use in connection with dwelling-houses ${ }^{69}$ (although, again, others have felt differently). ${ }^{70}$ On the whole, however, it is clear that warrants based on reasonable grounds are not standard constitutional prerequisites to searches in regulatory investigations. The opposite, of course, is true in criminal investigations.

\section{JUSTIFYING THE DISTINCTION}

So why the distinction? Why is it that the constitution seems to allow the state to compel admissible statements and engage in warrantless intrusions in regulatory investigations but not in criminal investigations?

Many reasons have been advanced to justify the distinction. It has been argued, for example, that regulated individuals effectively consent to invasions of their rights against self-incrimination and to privacy, ${ }^{71}$ that there is an inherent difference between true crimes and regulatory offences, ${ }^{72}$ and that regulatory laws could not be effectively enforced without the powers to compel statements and conduct warrantless intrusions. ${ }^{73}$ Arguably the primary justification, however, has been based on the suggestion that there is a different purpose

See e.g. R. v. Inco Ltd. (2001), 54 O.R. (3d) 495 at paras. 505-506 (C.A.), leave to appeal to S.C.C. refused, 160 O.A.C. 198 [Inco]; R. v. Morrell, 2004 NSPC 4, 221 N.S.R. (2d) 345; R. v. Kinnear (1997), 148 Nfld. \& P.E.I.R. 163 (P.E.I.S.C. (T.D.)), aff'd (1997), 151 Nfld. \& P.E.I.R. 83 (P.E.I.S.C. (A.D.)) [Kinnear]. In Inco the Ontario Court of Appeal interpreted the Supreme Court of Canada to have endorsed this test in Comité Paritaire de l'Industrie de la Chemise v. Potash; Comité Paritaire de l'Industrie de la Chemise v. Sélection Milton, [1994] 2 S.C.R. 406 [Potash]. to S.C.C. refused (1987), 50 Man. R. (2d) 79n; R. v. Nicol (1997), 98 O.A.C. 66 [Nicol]; Roback v. Chiang, 2003 BCPC 509, [2003] B.C.J. No. 3127 (QL). See e.g. R. v. Rhyno, 2002 NSPC 8, 204 N.S.R. (2d) 156 at para. 24; R. v. Cranford (1999), 180 Nfld. \& P.E.I.R. 248 at para. 46 (Nfld. Prov. Ct.).

See e.g. Johnson v. Ontario (Minister of Revenue) (1990), 75 O.R. (2d) 558 (C.A.); R v. Stengler, 2003 SKPC 119, 237 Sask. R. 278. Potash, supra note 64. It is not clear that the Supreme Court meant to lay down a universal rule in this case.

See e.g. R. v. MacAusland (1985), 52 Nfld. \& P.E.I.R. 349 (P.E.I.S.C. (A.D.)); R. v. Cake, [1996] B.C.J. No. 1655 (S.C.) (QL).

See e.g. R. v. Bichel (1986), 33 D.L.R. (4th) 254 (B.C.C.A.); Nicol, supra note 65; Potash, supra note 64 at $423-24$.

This is often referred to as the licensing argument: see e.g. Fitzpatrick, supra note 5 at paras. 40-41.

See e.g. Thomson Newspapers, supra note 3 at 509-11.

See e.g. McKinlay Transport, supra note 44 at 648-50. 
behind regulatory intrusions and inquiries. ${ }^{74}$ They are intended to ensure compliance with the law, not to gather evidence in support of a prosecution. It is criminal investigations that are intended to do the latter and thus it is in criminal investigations that the rights against selfincrimination and to privacy should receive added protection. I shall refer to this as "the purpose argument.”

The most important example of the purpose argument is found in the case so often mentioned above, Jarvis. In that case, the Supreme Court settled a long-standing dispute in the lower courts as to exactly when the prosecution is entitled to use evidence obtained through the use of the requirement powers of the Income Tax Act — namely, the powers to compel statements and, absent any warrant, inspect places and demand the production of documents. The Court distinguished between "compliance audits and tax evasion investigations," ${ }^{75}$ holding that it is only in the former that the prosecution is entitled to rely on evidence gathered through the requirement powers. Importantly, the Court defined and differentiated a tax evasion investigation based on its predominant purpose: "the determination of penal liability." rights. The Court did not explicitly assert that enhanced rights exist because of this purpose - only that enhanced rights exist when an investigation has that purpose - but the implication seems unavoidable: a test that distinguishes based on purpose must assume that purpose justifies the distinction.

The reasoning in Jarvis is obviously controlling in the tax context but, as discussed above, it has also been applied to the use of warrantless search and seizure powers in a wide variety of other regulatory contexts. ${ }^{77}$ It has also been applied in non-tax contexts to the use of powers to compel statements. ${ }^{78}$ The purpose argument has clearly exercised substantial influence over the constitutional distinction drawn between criminal and regulatory investigations.

The exact relevance of Jarvis in the self-incrimination context is, of course, not entirely certain. Other than in tax prosecutions, the constitutional distinction regarding compelled statements seems to be guided more by the decisions in Fitzpatrick and White. However, that does not diminish the significance of the purpose argument. The distinction drawn in Fitzpatrick and White is similarly based, in part, on purpose. In seeking to justify the constitutional distinction between criminal and regulatory investigations, White relied on the earlier analysis in Fitzpatrick. Fitzpatrick, in turn, relied on the purpose argument. In holding that statutorily compelled fishing reports were admissible in a prosecution for overfishing, the Court argued that

74 Assigning primary importance to a particular justification is almost impossible. Courts and commentators have relied upon a variety of justifications without ranking them in significance. But the references to purpose are so numerous, and from such high authorities, that it is clearly one of the major justifications, and arguably the primary one.

Supra note 7 at para. 2.

Ibid. at para. 88.

See e.g. Labrador Sea Products, supra note 62 (Fisheries Act, supra note 4); Romano, supra note 62 (The Wildlife Act, 1998, S.S. 1998, c. W-13.12); Canada Brick, supra note 33 (Occupational Health and Safety Act, R.S.O. 1990, c. O-1); Milligan, supra note 62 (Environment Act, S.N.S. 1994-95, c. 1).

$78 \quad$ See e.g. Rice, supra note 35 (Wildlife Act, R.S.B.C. 1996, c. 488); Kooktook, supra note 33 (Fisheries Act, ibid.). 
[t]he essential purpose of this requirement [to file fishing reports] is not to accumulate information that can later be used against the fishers who supply it. It is not compiled during the course of any investigation into wrongdoing. Instead, the purpose of the self-reporting obligation is to provide fisheries officials with up-todate information necessary for the effective regulation of the fishery. ${ }^{79}$

This was not the only argument advanced by the Court to justify the constitutional distinction, but it was one of them. ${ }^{80}$

Numerous other courts have also argued that the constitutional distinction can be justified based on purpose. The Ontario Court of Appeal, for example, upheld warrantless inspections under the Employment Standards Act, ${ }^{81}$ stating that " $\left.\mathrm{t}\right]$ he 'search or seizure' in the instant case ... is not aimed at detecting criminal activity, but rather ... in ensuring and securing compliance with the regulatory provisions of the Act enacted for the purpose of protecting the public interest." ${ }^{2}$ The Manitoba Court of Queen's Bench distinguished regulatory inspections from criminal searches, based largely on the argument that " $[\mathrm{t}] \mathrm{he}$ regulatory inspection is directed towards ensuring and securing compliance with the legislation in question.” ${ }^{33}$ The Prince Edward Island Supreme Court (Appellate Division) upheld warrantless inspection powers under the province's Environmental Protection Act, ${ }^{84}$ partly on the basis that "the purpose of [the relevant statutory provisions] ... is not to penalize criminal conduct but to enforce compliance with the Act.",85

Commentators have also argued that Charter rights should vary with investigatory purpose. David Stratas, for example, argued as follows:

Where the regulatory official's predominant purpose is regulatory verification and compliance ... the Charter plays a limited role, to ensure that no abuses of power take place. Where the regulatory official's activities are focussed on a particular individual, group of individuals or corporation and the predominant purpose is building a case for prosecution, the situation is analogous to police investigations into crime and the Charter protections should be no less than those enjoyed by suspects or targets in such investigations. ${ }^{86}$

Supra note 5 at para. 35.

See also McKinlay Transport, supra note 44 at 641, upholding the exercise of a warrantless demand for production power: "The Income Tax Act is essentially a regulatory statute since it controls the manner in which income tax is calculated and collected. This Court pointed out in R. v. Grimwood that 'the purpose of [the demand for production sections], when read together, is not to penalize criminal conduct but to enforce compliance with the Act'” [footnote omitted].

R.S.O. 1980, c. 137.

Re Belgoma Transportation Ltd. v. Ontario (Director of Employment Standards) (1985), 51 O.R. (2d) 509 at 512 (C.A.).

R. v. Bolczak, 2005 MBQB 56, 198 Man. R. (2d) 1 at para. 21.

R.S.P.E.I. 1988, c. E-9.

R. v. Island Farm and Fish Meal Ltd. (1992), 97 Nfld. \& P.E.I.R. 350 at para. 33 (P.E.I.S.C. (A.D.)).

David Stratas, "Charter Protections in Regulatory Proceedings: Do They Exist?" in Selected Topics in Corporate Litigation: Papers Presented at the 7th Queen's Annual Business Law Symposium 2000 (Kingston: Queen's Annual Business Law Symposium, 2001) 221 at 222-23 [footnote omitted] [Selected Topics in Corporate Litigation]. See also Ontario, Royal Commission Inquiry Into Civil Rights, Report Number One, vol. 1 (Toronto: Queen's Printer, 1968) at 415: "Where a statute is regulatory and its purpose is to safeguard the public, inspectors engaged in the enforcement of the statute must have powers of entry and, in some cases, of seizure, without judicial authority in either case as a condition precedent”; David M. Porter, "A Contextual Analysis of Section 8 Charter Rights in Regulatory Audits" (2002) 46 Crim. L.Q. 341 at 352-53: "It is submitted that ... where the purpose or one of the purposes of the [regulatory] investigators is to obtain evidence of an alleged crime, a search warrant should be required." 
The purpose argument has clearly been an important and persuasive one. But is it a valid one? I suggest not.

\section{Evaluating the Purpose Argument}

\section{A. Filling in the Argument}

In order to evaluate the purpose argument it is first necessary to better understand it. The argument is somewhat confusing. In particular, it is hard to know what the courts mean by "ensuring compliance," the objective that is assumed to motivate regulatory enforcement. ${ }^{87}$ The comments in Fitzpatrick and other cases might be taken to suggest that it refers to managing a regulated industry, in the sense of setting quotas, issuing licences, devising standards, collecting levies - everything other than investigating offences. But that would not be accurate. Numerous cases have held that state officials were ensuring compliance even when they were exploring the possibility or even the suspicion that an offence had occurred. ${ }^{88}$ The cases have also held that information collected in such circumstances, even through warrantless inspection or statutory compulsion, can be used as evidence in a later prosecution.

If “ensuring compliance” includes investigating offences, what distinguishes it from criminal enforcement? The case law has not provided much of an answer to that question. Commonly, judicial decisions simply refer to "ensuring compliance" as if the meaning of the term was self-evident. Thankfully, however, some decisions have provided some clues, and when one factors in the relevant literature a generalized answer emerges.

The distinction between regulatory enforcement and criminal enforcement seems to turn on overall enforcement strategy. Regulatory enforcement is thought to be more proactive and only exceptionally interested in prosecuting offenders. Information is collected, but the initial intent is not to use the information as evidence in a legal proceeding; it is, rather, to educate offenders (and non-offenders) and correct and prevent problems. Criminal enforcement, on the other hand, is thought to be more reactive and acutely focused on prosecution as a response to wrongdoing. Information is collected in order to be used as evidence. Comparing a compliance strategy of enforcement (typical of regulatory enforcement) and a "sanctioning” strategy (more typical of criminal enforcement), ${ }^{89}$ Bridget Hutter described the difference as follows:

[A compliance strategy of enforcement] is co-operative and conciliatory in style and its aim is to secure compliance through the remedy of existing problems and, above all, the prevention of others. Where compliance is less than complete the preferred methods of achieving full compliance are persuasive and educative. The use of formal legal methods, especially prosecution, is regarded as a last resort.... Another

"Ensuring compliance" is not a term of art but simply the phrase most commonly employed in the case law.

See e.g. Potash, supra note 64; Kinnear, supra note 64; R. v. Leahy, 2004 NSPC 62, 229 N.S.R. (2d) 32. In fact, the rights to privacy and against self-incrimination are not necessarily engaged even when the regulatory official has reasonable grounds to believe that an offence has occurred: see e.g. Milligan, supra note 62; Diep, supra note 51.

As discussed in Part IV.C, below, a compliance strategy is sometimes employed in criminal enforcement. 
characteristic of such a [strategy] is that it allows for compliance over a period of time; instant remedy is not necessarily sought or considered possible.

The sanctioning strategy is basically a punitive approach to law enforcement. Its objective is to prohibit certain activities and where this fails to seek out offenders and punish them for their wrongdoing. Compliance may be a consequence of such a strategy but it is not a central rationale for enforcement. Prosecution, however, is an important ingredient of a sanctioning strategy.... Essentially this is an accusatory enforcement style which is geared to catching out those who break the law with the objective of punishing them, most particularly through the use of formal legal methods, such as prosecution. ${ }^{90}$

Keith Hawkins has added that in a sanctioning strategy there is special concern for proof of violation, whereas in a compliance strategy there is much less concern for proving a violation took place. "Detection is important, ... but ... as a means of monitoring compliance and of enhancing prevention." 91

Although I am not aware of any court decision that specifically endorses the definitions offered by Hutter and Hawkins, there is good reason to believe that they captured the concepts that the courts have in mind when they distinguish "ensuring compliance" from criminal enforcement. Certainly, when it comes to the interpretation of Charter rights, it is the fact that officials are using statutory compulsions and warrantless intrusions to collect evidence for prosecution that seems to be of most concern; it is said to create an adversarial relationship between the state and the individual. Thus, in Jarvis the Supreme Court held that the constitutional rules change when the predominant enforcement purpose is "the determination of penal liability." ${ }^{\text {"I }}$ In Branch the Supreme Court held that the critical constitutional question was whether testimony was being compelled "to incriminate the witness" in another proceeding ${ }^{93}$ (incrimination being intimately connected with prosecution). ${ }^{94}$ The Ontario Court of Justice (General Division) stated that a "clear distinction has been drawn between criminal or quasi-criminal searches aimed at discovering evidence for use in criminal proceedings and administrative searches aimed more at ensuring compliance with regulatory statutes." ${ }^{\text {,95 }}$

By the same token, it is considered significant that regulatory enforcement is, at least initially, focused on obtaining information for uses other than prosecution. In Potash, for example, La Forest J. noted that inspections are not intended to uncover offences, but to protect the public. ${ }^{96}$ In McKinlay Transport, Wilson J. stressed that the power under the

Bridget M. Hutter, The Reasonable Arm of the Law? The Law Enforcement Procedures of Environmental Health Officers (Oxford: Clarendon Press, 1988) at 6-7 [Hutter, Reasonable Arm]. Keith Hawkins, Environment and Enforcement: Regulation and the Social Definition of Pollution (Oxford: Clarendon Press, 1984) at 5 [Hawkins, Environment and Enforcement].

Supra note 7 at para. 2.

Supra note 59 at para. 9 .

"Incriminating evidence means something from which a trier of fact may infer that an accused is guilty of the crime charged": Henry, supra note 8 at para. 25 [internal quotation marks omitted].

R. v. Bjellebo, [1999] O.J. No. 965 at para. 143 (Ct. J. (Gen. Div.)) (QL).

Supra note 64 at 416-17, citing Lucie Angers, "À la recherche d'une protection efficace contre les inspections abusives de l’État: la Charte québécoise, la Charte canadienne et le Bill of Rights américain” (1986) 27 C. de D. 723 at 727-28. 
Income Tax Act to demand, without warrant, the production of documents was "not

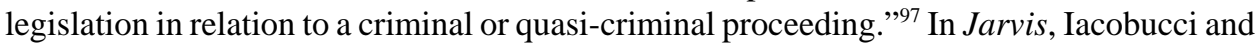
Major JJ. held that Charter rights are different when enforcement powers are used to assess tax liability rather than prosecute offences. ${ }^{98}$ In Fitzpatrick, La Forest J. emphasized that the purpose of the reporting requirement was "not to accumulate information that can later be used against the fishers who supply it." 99 An initial non-prosecutorial enforcement purpose has been given similar significance by the United States Supreme Court, ${ }^{100}$ judicial inquiries, ${ }^{101}$ government departments, ${ }^{102}$ and numerous legal commentators. ${ }^{103}$

\section{B. Theoretical Problems}

It is a little ironic that it is usually in cases where information obtained by statutory compulsion or warrantless intrusion is being adduced as evidence in a prosecution that the courts stress that the information was not collected with that purpose in mind. One could be forgiven for asking whether the original purpose really matters anymore: the intent has changed by the time of trial! But this curiosity is actually instructive as to the real concerns animating and not animating the purpose argument. It shows that the concern is not over the state intending to use information obtained (previously) without warrant or under statutory compulsion as evidence in a prosecution. The concern is over compelling statements or intruding upon privacy without warrant in order to use the information as evidence. The courts are focusing their attention, in other words, on how the initial objective of the state actor affects the fairness of the trial and/or reliability of the evidence. Careful analysis,

\section{Supra note 44 at 641 .}

Supra note 7 at paras. 68-71, 77, 94-96.

Supra note 5 at para. 35. See also Wholesale Travel, supra note 3 at 219, where Cory J. contended that regulatory measures are intended to prevent future harm, while criminal offences are designed to condemn and punish.

Frank v. Maryland, 359 U.S. 360 at 366 (1959) [Frank]:

The attempted inspection of appellant's home is merely to determine whether conditions exist which the Baltimore Health Code proscribes. If they do appellant is notified to remedy the infringing conditions. No evidence for criminal prosecution is sought to be seized. Appellant is simply directed to do what he could have been ordered to do without any inspection, and what he cannot properly resist, namely, act in a manner consistent with the maintenance of minimum community standards of health and well-being, including his own.

See e.g. Royal Commission Inquiry Into Civil Rights, supra note 86 at 415: “[Regulatory] inspections are not primarily for the purpose of detecting offenders in order that prosecutions may be launched, nor for securing evidence to support prosecutions. Their primary purpose is educative and disciplinary in character, to secure compliance with the statutes"; Ontario, Ministry of the Attorney General, Report of the Walkerton Inquiry: A Strategy for Safe Drinking Water, Part 2 (Ontario: Ministry of the Attorney General, 2002) at 60 (Commissioner: Dennis R. O’Connor) (defining inspection as a "method of achieving compliance short of investigation and enforcement”).

See e.g. Environment Canada, Compliance and Enforcement Policy for the Canadian Environmental Protection Act, 1999 (CEPA, 1999) (Ottawa: Minister of Public Works and Government Services Canada, 2001) at 18-20; Environment Canada, Compliance and Enforcement Policy for the Habitat Protection and Pollution Prevention Provisions of the Fisheries Act (Ottawa: Minister of Public Works and Government Services Canada, 2001) at 17-23 (distinguishing between inspections and investigations).

See e.g. Neil Brooks \& Judy Fudge, Search and Seizure under the Income Tax Act: A Study Paper prepared for the Law Reform Commission of Canada (Ottawa: Law Reform Commission, 1985) at 9, 66; “The Fourth Amendment and Housing Inspections,” Note, (1968) 77 Yale L.J. 521 at 534; Sally S. Simpson, Corporate Crime, Law, and Social Control (Cambridge: Cambridge University Press, 2002) at 79; Charles R. McManis \& Barbara Mayes McManis, "Structuring Administrative Inspections: Is There Any Warrant For A Search Warrant?” (1977) 26 Am. U. L. Rev. 942 at 946; Jamie Benidickson, Environmental Law, 2d ed. (Toronto: Irwin Law, 2002) at 125, citing D. Saxe, Inspections and Searches in the Environmental Context (Toronto: Environment Ontario, 1987); Law Reform Commission of Canada, Strict Liability: Working Paper No. 2 (Ottawa: Information Canada, 1974) at 32. 
however, shows that a focus on prosecutorial purpose does not safeguard the fairness of a trial or protect against the admission of unreliable evidence.

\section{FAIRNESS}

How can a prosecutorial purpose render unfair the admission of evidence collected by warrantless intrusion or statutory compulsion? The courts have yet to clearly explain, but the answer apparently has to do with the principle against self-incrimination. That principle holds that "the individual is sovereign and ... proper rules of battle between government and individual require that the individual ... not be conscripted by his opponent to defeat himself." 104 The principle is considered one of the principles of fundamental justice under s. 7 of the Charter, and thus one of the fundamental tenets of our justice system. ${ }^{105}$ In simple terms, it means that " $[\mathrm{w}]$ here the state alleges wrongdoing, it cannot force the target of that allegation to assist the state in proving the allegation." ${ }^{106}$ At least arguably, a prosecutorial purpose combined with a statutory compulsion or warrantless intrusion results in a situation where an individual is forced to contribute to her own prosecution.

This is most obvious in connection with compelled statements. The individual is being forced to do something (speak to the authorities) and the state intends to use the resulting information to prosecute the individual. The contention is much weaker in the case of warrantless intrusions, but arguably still available. ${ }^{107}$ With a prosecutorial purpose, the state clearly intends to use any information obtained to prosecute the person suffering the intrusion. The person is not actively forced to do anything, but she is forced to give up something (namely, her privacy and right to exclude the state) and in that sense she might be considered to contribute to the prosecution.

One searches the case law in vain for an explicit assertion that the purpose argument is based upon the principle against self-incrimination (or any principle), but the conclusion seems highly likely. Consider, for example, the decision in Fitzpatrick, where the Supreme Court ruled that statutorily-required fishing reports were admissible in a prosecution for overfishing. ${ }^{108}$ As noted above, in coming to its decision the Court relied in part on the purpose argument. More specifically, the Court referred to purpose in determining the applicability of the principle against self-incrimination. That principle was said to be violated by "[a]ny state action that coerces an individual to furnish evidence against him- or herself in a proceeding in which the individual and the state are adversaries." 109 The nonprosecutorial purpose for requiring the fishing reports dictated that the individual and the state were not adversaries (at the time the reports were required) and thus that the principle did not apply. It is difficult to read Fitzpatrick as anything other than an indirect assertion that purpose is relevant because it impacts on whether a person is being forced to contribute to her own prosecution. The same may be said for the Court's decision in Jarvis, which again

R. v. Jones, [1994] 2 S.C.R. 229 at 248 [Jones], quoting John Henry Wigmore, Evidence in Trials at Common Law, rev. ed. by John T. McNaughton (Boston: Little, Brown, 1961) vol. 8 at 318, § 2251. See White, supra note 12 at paras. 40-42. It is, of course, largely in reference to those tenets that the law determines fairness.

R. v. D’Amour (2002), 163 O.A.C. 164 at para. 35.

See Frank, supra note 100 at 363-65; Entick v. Carrington (1765), 95 E.R. 807.

Supra note 5.

Ibid. at para. 33, quoting Jones, supra note 104 at 249 [emphasis added]. 
focused on the principle against self-incrimination (similarly defined) ${ }^{110}$ and again determined that the principle is not violated when the predominant purpose for state action is not the determination of penal liability. ${ }^{111}$ Importantly, Jarvis also extended this reasoning to cover warrantless intrusions, holding that the principle (and s. 7 of the Charter) is violated when tax officials seeking to determine penal liability collect financial documents without warrant. ${ }^{112}$

Legal analysis of the principle against self-incrimination is more nuanced than the simple proposition that someone cannot be forced to contribute to her own prosecution, but the nuances do not dispel the suggestion that the purpose argument is grounded in the principle. In determining the application of the principle, the courts generally consider three factors: whether the evidence was obtained by state coercion, whether an adversarial relationship existed between the individual and the state, and whether there was a risk of an abuse of state power. ${ }^{113}$ These three factors are really just indicia of whether a person is being forced to contribute to her own prosecution. The coercion factor speaks to whether there is a forced contribution. The adversarial relationship factor speaks to whether the state has a prosecutorial purpose; an adversarial relationship exists not just when the interests of the individual and the state conflict, but when the state is investigating possible misconduct for purposes of possible prosecution. ${ }^{114}$ The abuse of state power factor is poorly defined but speaks, at least in part, to the presence of a prosecutorial purpose. The Supreme Court in White, for example, held that there was a risk of an abuse of state power because a police officer receiving a statutorily compelled motor vehicle accident report might be tempted to "overemphasize the extent of the statutory duty ... in order to obtain relevant information" for a criminal investigation. ${ }^{115}$ The abuse factor also seems to speak to the invasiveness of the state action on a person's privacy, ${ }^{116}$ but that does not appear to be a significant issue in the current interpretation of the principle against self-incrimination. ${ }^{117}$

The basis for the principle against self-incrimination (which, in turn, is supposed to support the purpose argument) is open to debate. Numerous justifications have been

$110 \quad$ Supra note 7 at para. 67.

$111 \quad$ Ibid. at paras. 85-92.

$112 \quad$ Ibid. at paras. 95-97.

113 See White, supra note 12 at para. 51. White also considered a fourth factor: namely, whether there was an increased risk of unreliable confession, but that factor relates to reliability rather than fairness. It will be considered separately in Part IV.B.2, below.

114 See e.g. Ling, supra note 26 at paras. 1-5, where the Supreme Court stated that an adversarial relationship "is engaged where the predominant purpose of an inquiry is the determination of ... penal liability." That an adversarial relationship is not created whenever the interests of the state and the citizen conflict is made evident by decisions like Fitzpatrick, supra note 5 at paras. 35-36, where the Court determined that an adversarial relationship was not present when the state prohibited Fitzpatrick from catching as many fish as he wanted to catch.

115 Supra note 12 at para. 64.

116 The Court in White, ibid. at para. 66, for example, considered (somewhat fancifully) that an accident report might contain "a personal narrative of events, emotions, and decisions that are extremely revealing of the declarant's personality, opinions, thoughts, and state of mind.”

117 This is suggested by the decision in White, ibid. at paras. 71-77, itself. While the Court mentioned the personal nature of the information that might be revealed in an accident report, it rejected the suggestion that the principle was any less engaged in connection with extremely impersonal information like the driver's name, address and acknowledgment that she was driving at the time of the accident. Even if invasiveness is a relevant issue in the interpretation of the principle against self-incrimination (as I believe it should be) this would not show that it is not believed that forcing someone to contribute to her own prosecution is unfair. It would simply show that a forced contribution was believed to be unfair except, perhaps, when the impact on privacy was limited. 
offered. ${ }^{118}$ The one that seems most applicable to the purpose argument, however, is the justification based on the right of self-preservation. ${ }^{119}$ This is the idea that people have a basic right not to be compelled to contribute to their own downfall. The idea is grounded in either a theory of natural rights or the compact theory of government. ${ }^{120}$ In the former theory, it is claimed that "self-preservation is a law of nature, and to force a person to contribute to the loss of his life, limb, or liberty is against the law of nature." ${ }^{121}$ In the latter theory, it is claimed that

[t]he state [is] merely an instrument created by contract in which rulers and the ruled [are] parties on equal terms....

A sovereign state has the right to defend itself, and within the limits of accepted procedure, to punish infractions of the rules that govern its relationships with its sovereign individuals. But it has no right to compel the sovereign individual to surrender or impair his right of self-defence....

To require it [mea culpa] is to insist that the state is the superior of the individuals who compose it, instead of their instrument. ${ }^{122}$

To be clear, the courts have never explicitly offered the right of self-preservation as a justification for the purpose argument (as opposed to the principle against self-incrimination). The purpose argument has never been detailed that thoroughly. On the assumption, however, that it is the self-preservation justification that at bottom drives the purpose argument, I will begin my reply by pointing out the two biggest flaws with the justification. I will then turn to a more general criticism of the purpose argument grounded in the principle against selfincrimination, whatever the argument's ultimate justification.

The first flaw in the self-preservation justification is that it will routinely fail the utilitarian calculus. The justification offers no concrete explanation of the benefits to be gained from protection against self-incrimination. ${ }^{123}$ The natural rights theory suggests that some law of nature will be protected, but how does that help us? The compact theory suggests that the state will remain the instrument of the people, but when the state compels the guilty to incriminate themselves is it not acting as the people's instrument? Compelled selfincrimination should facilitate conviction and punishment of those who commit serious

See David Dolinko, “Is There a Rationale for the Privilege Against Self-Incrimination?” (1986) 33 UCLA L. Rev. 1063.

This sort of justification has been favoured by the Supreme Court of Canada: see Steven Penney, "What's Wrong with Self-Incrimination? The Wayward Path of Self-Incrimination Law in the PostCharter Era. Part I: Justifications for Rules Preventing Self-Incrimination” (2003) 48 Crim. L.Q. 249 at 250 [Penney, "Part I"].

There is no closed or officially accepted list of explanations for why there is a right not to contribute to your own downfall, but the theory of natural rights and compact theory of government are the most notorious explanations.

Kenneth I. Winston, "Self-Incrimination in Context: Establishing Procedural Protections in Juvenile and College Disciplinary Proceedings" (1975) 48 S. Cal. L. Rev. 813 at 824.

Abe Fortas, "The Fifth Amendment: Nemo Tenetur Prodere Seipsum” (1954) 25 Cleveland Bar Assoc. J. 91 at $98-100$.

This is not really surprising, of course, because the justification is deontological, not utilitarian. The justification does not calculate costs and benefits, it simply asserts what is or what should be. The natural rights theory asserts that the law of self-preservation exists. The compact theory describes not an historical event but a preferred view of the state-citizen relationship. The justification, in other words, is conclusive. It dictates by its own terms the unfairness of forcing someone to contribute to her own prosecution. My question is: why should we accept its terms? 
crimes. Clearly there is a lot to be gained by such convictions. The benefits from convicting perpetrators of minor crimes may be less, but the harm to the perpetrators from selfincrimination is likely to be trivial. ${ }^{124}$ There will probably be some situations where protection against self-incrimination produces a net benefit, but that will certainly not always be the case. ${ }^{125}$ This is a real problem for a justification of the principle against selfincrimination that fails to offer any concrete explanation of its benefits. ${ }^{126}$

The other major flaw with the self-preservation justification is that the law routinely disregards its dictates. We prohibit people from destroying evidence, resisting arrest, fleeing the jurisdiction, suborning perjury, and obstructing the course of justice, even though it hinders their ability to preserve themselves from loss of liberty. ${ }^{127}$ We extract blood samples, breath samples, and fingerprints from people even though it compels them to surrender or impair their "right" of self-defence. ${ }^{128}$ We force parents to testify against their own children, even though it presumably imposes an enormous cost to their psychic integrity and wellbeing. ${ }^{129}$ Why should we only care about self-preservation when it comes to utterances? In fact, a good argument could be made that, in effect, we disregard the dictates of the selfpreservation justification even in relation to utterances. We countenance closed-door "pressurized, manipulative questioning" of suspects by the police ${ }^{130}$ even though we know that despite the legal right to remain silent a great many suspects will incriminate themselves in response. ${ }^{131}$

See e.g. Penney, "Part I," supra note 119 at 259-60; R. Kent Greenawalt, "Silence as a Moral and Constitutional Right” (1981) 23 Wm. \& Mary L. Rev. 15 at 29-30.

Note that we must include in the calculation any cost to the innocent from the principle against selfincrimination: Lewis Mayers, Shall We Amend the Fifth Amendment? (Westport, Conn.: Greenwood Press, 1959) at 166. An innocent accused may suffer, for example, from her inability to force her guilty co-accused to testify.

Even if the self-preservation justification did offer some explanation of the benefits from protection against self-incrimination, the protection would still be hard to defend: see Ian Dennis, "Instrumental Protection, Human Right or Functional Necessity? Reassessing the Privilege Against Self-Incrimination" (1995) 54 Cambridge L.J. 342 at 375 [emphasis in original]:

The fundamental objection to the use of compulsion ... is that it amounts to treating a suspect as an object for the extraction of evidence. On Kantian principles this is prima facie an infringement of the core value attached to the claims of all human beings to respect and dignity. Recognizing the validity of this claim does not commit us to saying that infringements can never be justified.... [I]t would tend to defeat most of the aims of criminal justice if the accused could never be used as a source of incriminating evidence. As a practical reality it is very doubtful whether any society could afford to give effect to all possible primary and derivative applications of the privilege [against self-incrimination]. It is therefore possible to say that the public interest in the enforcement of the criminal law by means of legitimate verdicts at criminal trials may provide the necessary justification for overriding the core value. Penney, "Part I," supra note 119 at 261. R. 1 (C.A.); R. v. Altseimer (1982), 38 O.R. (2d) 783 (C.A.); R. v. Beare (1987), [1988] 2 S.C.R. 387. Mayers, supra note 125 at $168-69$.

Penney, "Part I," supra note 119 at 263.

Mayers, supra note 125 at 84 . In a survey of American interrogations, Richard A. Leo found that only about 20 percent of suspects remained silent: "Inside the Interrogation Room" (1996) 86 J. Crim. L. \& Criminology 266 at 275-76. Other studies have reported even lower numbers: Paul G. Cassell \& Bret S. Hayman, "Police Interrogation in the 1990s: An Empirical Study of the Effects of Miranda" (1996) 43 UCLA L. Rev. 839 at 860 (reporting that only 12.1 percent of suspects invoked their Miranda rights); U.K., Royal Commission on Criminal Procedure, Police Interrogation: an observational study in four police stations (Research Study No. 61) by Paul Softley et al. (London: Her Majesty's Stationery Office, 1980) 49 at 74 (reporting that only 9 percent of suspects refused to answer some or all questions during interrogation); U.K., Royal Commission on Criminal Justice, The Right to Silence in Police Interrogation: A Study of Some of the Issues Underlying the Debate (Research Study No. 10) by Roger Leng (London: Her Majesty’s Stationery Office, 1993) at 17 (reporting that only 4.5 percent of suspects exercised their right to silence). 
Even if one moves beyond the self-preservation justification and considers the purpose argument grounded in the principle against self-incrimination, however justified, there are at least three serious problems. First of all, the argument really has no relevance to warrantless intrusions. The subject of the intrusion is not really being forced to contribute to her own prosecution. She is forced to give up her privacy and right to exclude the state, but that is a highly passive sort of contribution. She is not forced to actually do anything. Charter jurisprudence does not normally consider evidence to be conscripted if the person did not more actively (or at least more personally) participate in its creation or discovery. ${ }^{132}$

The relevant issue in regards to warrantless intrusions is not conscripted incrimination, but privacy. An investigation's impact on privacy, however, does not necessarily vary with its purpose. If a housing inspector enters your home, your privacy is lost no less than when a police officer enters your home. ${ }^{133}$ It may be that the ultimate extent of the state invasion will be greater in criminal enforcement - the police may examine your whole house and not just your electric wiring - but in that case the relevant issue is the level of invasiveness, not the reason for it. ${ }^{134}$ Even if criminal enforcement routinely or inevitably results in a more extensive invasion, purpose can serve as nothing more than shorthand that diverts analysis from the real issue. It may also be that the person whose privacy is being invaded will personally feel a greater invasion in the context of criminal enforcement, but that is because of the possible repercussions of the invasion rather than the purpose for it. ${ }^{135}$ Someone who may be charged with robbery, in other words, will probably feel more threatened than a person who may be cautioned for health code violations because she is more likely to be imprisoned and/or stigmatized. But by the same token, a person who may be pressured to incur a large expense to come into regulatory compliance will probably feel more threatened than a person who may be prosecuted and sentenced to an absolute discharge.

Second, the purpose argument characterizes the purpose of regulatory enforcement too narrowly. While there is no question that regulatory enforcement (or, more accurately, a compliance strategy of enforcement that is common to regulatory enforcement) is primarily aimed at securing compliance through non-prosecutorial means, ${ }^{136}$ it is unrealistic to compartmentalize enforcement styles as non-prosecutorial or prosecutorial. Prosecution is a part of regulatory enforcement. ${ }^{137}$ The very fact that it is sometimes resorted to is proof of that. But the connection between prosecution and compliance enforcement runs deeper. The possibility of prosecution makes compliance enforcement possible. Hawkins has stated it well:

See R. v. Stillman, [1997] 1 S.C.R. 607 at 651-71.

Scott E. Sundby, "A Return to Fourth Amendment Basics: Undoing the Mischief of Camara and Terry" (1988) 72 Minn. L. Rev. 383 at 408; Ronald F. Wright, "The Civil and Criminal Methodologies of the Fourth Amendment” (1984) 93 Yale L.J. 1127 at 1136.

Wayne R. LaFave, “Administrative Searches and the Fourth Amendment: The Camara and See Cases” (1967) Sup. Ct. Rev. 1 at 17-19.

Wright, supra note 133 at 1136.

See e.g. Kernaghan Webb, Pollution Control in Canada: The Regulatory Approach in the 1980s (Study Paper) (Ottawa: Law Reform Commission of Canada, 1988) at 18-23; Law Reform Commission of Canada, Policy Implementation, Compliance and Administrative Law (Working Paper 51)(Ottawa: Law Reform Commission of Canada, 1986).

See e.g. Gary T. Trotter, "Prosecution is Regulation: A Reply To David Stratas" in Selected Topics in Corporate Litigation, supra note 86, 252 at 252-53; James Sprague, “Good Cop/Bad Cop: Charter Rights Against Self-Incrimination and Unreasonable Search and Seizure in the Context of Investigations in Support of a Regulatory Scheme” (2002) 16 Can. J. Admin. L. \& Prac. 161 at 174. 
[Prosecution] is the device that makes all other law enforcement possible by granting credibility to more private and informal practices and thereby, in the great majority of cases, foreclosing the possibility of costly prosecution and trial.

Though it is not actually used much, prosecution is central to systems of negotiated compliance. It is constantly employed, but in the background, as a veiled threat to concentrate the rule-breaker's mind on the necessity of compliance. ${ }^{138}$

It is, accordingly, somewhat disingenuous to characterize as non-prosecutorial even the initial regulatory purpose for compelling a statement or intruding without warrant. Compliance officers will avoid using the resulting information for prosecution if they can, but will use it for prosecution if they must. ${ }^{139}$ It is therefore fair to say that a secondary purpose for compliance regulatory enforcement is prosecution. State officials deliberately and necessarily reserve themselves the right to prosecute. ${ }^{140}$ As a result, the regulated individual is forced to contribute to her own prosecution every time she is compelled to give a statement or (I will assume) admit inspectors, even if the contribution is only potential and not actualized. The principle against self-incrimination is protected only to the extent that the violation is limited, not absent.

In truth, often it is more accurate to characterize a regulator's initial enforcement purpose as uncertain rather than prosecutorial or non-prosecutorial. ${ }^{141}$ How a regulator reacts to an offence depends in part (and to varying extents) on the circumstances of the offence and offender. ${ }^{142}$ A regulator usually does not fully understand those circumstances until after an investigation has begun. In many cases, therefore, the real initial purpose for regulatory enforcement is to determine whether a compliance or prosecutorial strategy should be employed, either in accordance with or despite any initial enforcement preference. Furthermore, it is sometimes the information collected by compelled statements and warrantless intrusions that determines whether a prosecutorial strategy is pursued. In regulatory enforcement, prosecution is generally employed in three situations only: where the regulated individual persistently refuses to come into compliance, where the damage caused by non-compliance is extensive, and where non-compliance is deemed to be morally blameworthy because it or the ensuing damage was either intentional or clearly

Keith Hawkins, Law as Last Resort: Prosecution Decision-Making in a Regulatory Agency (Oxford: Oxford University Press, 2002) at 13, 42 [Hawkins, Law as Last Resort]. See also Todd L. Archibald, Kenneth E. Jull \& Kent W. Roach, Regulatory and Corporate Liability: From Due Diligence to Risk Management (Aurora, Ontario: Canada Law Book, 2004) at 14-8. statement. See Maitland Valley Conservation Authority v. Cranbrook Swine Inc., [2004] O.J. No. 5724 (Ct. J.) (QL), for a good example of regulatory officials pursuing a prosecutorial strategy as a fallback to a compliance strategy.

This will not always be true because a few regulators will effectively rule out any possibility of prosecution $a b$ initio.

In her study of the enforcement of occupational health and safety laws, Bridget M. Hutter stressed that "[r] egulatory officials are case driven and make case-by-case judgements rather than adhering to abstract principles to guide their work": "Controlling Workplace Deviance: State Regulation of Occupational Health and Safety” in Ida Harper Simpson \& Richard L. Simpson, eds., Research in the Sociology of Work: Deviance in the Workplace, vol. 8 (Stamford, Conn.: Jai Press, 1999) 191 at 201. 
foreseeable. ${ }^{143}$ It is sometimes only by compelling statements and intruding without warrant that the last two situations (especially the last) come to light. But this means that the constitutionality of enforcement action is being judged according to a purpose that did not yet exist. This is what the purpose argument specifically disavows. As stated above, the argument focuses on purpose at the time information is collected, not purpose as determined (for the first time) later on. If the purpose argument is more nuanced than I have assumed and it does acknowledge the relevance of ex post facto purpose, one must ask why purpose at an even later time - the time of trial — is considered irrelevant.

This leads into the last problem with the purpose argument as grounded in the principle against self-incrimination. The argument, as advanced by the courts, undermines any meaningful protection against self-incrimination. As noted, the issue of concern for the courts is the initial investigative purpose. It does not matter that the purpose may ultimately change and information previously collected may end up being used to prosecute. What matters is whether the information was collected in order to prosecute. But this suggests that what is pernicious is the desire to force someone to contribute to her own prosecution, rather than the act of forcing someone. The focus is on the motivations of the state actor rather than the effect of the state action. This is perverse. A person is no less forced to contribute to her own prosecution when her compelled statement ends up being used against her than when her statement is compelled in order to be used against her; in either case, at the time of trial information that was forced from the person contributes to the prosecution. The principle of self-incrimination protected by the courts is not the principle that the individual not be conscripted by her opponent to defeat herself, but the principle that the individual not be deliberately conscripted by her opponent to defeat herself, at least at the time the information is collected, although the opponent is free to change his mind later on such that the individual is effectively conscripted to defeat herself. Is any meaningful principle against selfincrimination left? It is cold comfort to the accused to know that at some point in the past the state officials prosecuting her now did not really mean to force her to contribute to her own downfall.

Indeed, the purpose argument, as it is currently applied, results in the situation where state agents can, in effect, determine the extent of a person's constitutional rights. We have granted public authorities the power to encroach upon privacy and compel statements on the assumption that their purpose is "benign," to later change their minds and adopt a different purpose, and thereby to determine whether or not a person really has, in the particular case, a certain level of constitutional protection. This turns constitutional reasoning on its head. Rights are meant to limit the power of government. The power to determine the scope of that limitation cannot be given to government.

The only legitimate basis for adjudging state action in light of the principle against selfincrimination is to consider its effect. Does the state action have the effect of forcing someone to contribute to her own prosecution? If so, the principle is violated. The individual

143 Hawkins, Law as Last Resort, supra note 138, c. 10. See also Genevra Richardson, "Strict Liability for Regulatory Crime: the Empirical Research” [1987] Crim. L. Rev. 295; Webb, supra note 136 at 21-22. Other factors, such as the public visibility of an offence or its effects and the perceived receptiveness of the courts, also impact on the decision to prosecute. 
is "conscripted by his opponent to defeat himself."144 But this, of course, would destroy the relevance of the purpose argument as a basis for distinguishing between rights in regulatory and criminal contexts. ${ }^{145}$ In either context, when a compelled statement or (supposedly) information collected from a warrantless intrusion is introduced into evidence, the principle against self-incrimination would be violated because the effect in both contexts would be the same. Neither the nature of the alleged offence nor the reason why it was initially investigated would alter the effect.

\section{RELIABILITY}

Even if purpose does not impact the fairness of introducing into evidence compelled statements or information collected by warrantless intrusion, it could impact the reliability of the evidence. The courts have, in fact, justified the principle against self-incrimination in part on the basis that it protects against the admission of unreliable information at trial. In B.(S.A.), for example, the Supreme Court stated that one of the two rationales for the principle against self-incrimination is to protect against unreliable confessions or evidence. ${ }^{146}$

A focus on purpose would certainly be appealing if it actually protected against unreliable confessions or evidence. The reality, however, is that it does not (at least not very well).

It is hard to fathom how a prosecutorial purpose (the issue of critical interest to the purpose argument) could impact the reliability of evidence obtained in the course of a search. A search seeks out pre-existing evidence. The intentions of the searcher will not affect whether such evidence exists. A prosecutorial versus a non-prosecutorial purpose might affect how the authorities deal with exculpatory evidence; it might lead them to misinterpret it, alter it, conceal it, destroy it, etc. But all these misuses occur after the evidence has been obtained. The possibility that they will occur offers no direct reason to restrict, by requiring a warrant, the ability to access the information. A warrant would only protect reliability to the extent that it prevented a corrupt investigator from planting evidence by restricting the investigator's access to the location where the evidence would be planted. One could argue that an investigator is more likely to plant evidence if she is collecting information in order to prosecute rather than ensure compliance. But if the investigator is so corrupt the reality is that a warrant requirement will probably do little to thwart her plot. She will simply fabricate the evidence necessary to obtain one. A warrant requirement might also be said to protect reliability prophylactically by limiting an investigator's access to materials that she may subsequently misuse (that is, by giving investigators fewer opportunities to misuse evidence). However, it would be a rather inefficient means of addressing the concern: it would protect reliability very indirectly at the cost of restricting investigative access to a massive amount of important information that would not be misused. Indeed, if we are so worried about misuse that we are willing to adopt such a prophylactic measure, then perhaps we should be transferring responsibility for collecting and using information to another state agency altogether. A warrant requirement would also do nothing to address the problem of misuse once access to the information was obtained. In fact, it might even exacerbate the

\footnotetext{
$144 \quad$ Wigmore, supra note 104.

145 I am only talking about penal contexts.

$146 \quad$ Supra note 128 at para. 57.
} 
problem. If a prosecutorial purpose inclines investigators to misuse evidence, then a prosecutorial purpose along with reasonable grounds to believe in the suspect's guilt will only increase the likelihood of misuse; the investigators will feel, and will actually receive judicial confirmation, that their beliefs are correct and thus that misuse is justified in the search for the greater good. ${ }^{147}$

It is easier to understand how a prosecutorial purpose might contribute to unreliability in connection with compelled statements. Investigators would be trying to gather evidence of guilt and thus they might be inclined to use the statutory requirement to answer questions as an opportunity to pressure, or even bully suspects into making admissions or confessions. ${ }^{148}$ Some of those statements may be false. In fact, false confessions and admissions are a recognized problem contributing to wrongful convictions. ${ }^{149}$ Affording a constitutional right that leads to the exclusion of compelled statements in circumstances where they are more likely to be false would therefore seem to be logical. ${ }^{150}$

A focus on purpose in this context has some appeal, but it suffers from two fairly significant problems. First of all, it probably offers only limited protection against unreliable statements. One cannot assume that false statements will never be made in response to lowpressure "compliance" questioning. Although our knowledge of the causes of false confessions is still limited, it certainly appears that they are not just the product of highpressure questioning. They can also result from vulnerabilities internal to the person being questioned. ${ }^{151}$ It is rather dangerous to assume that such vulnerabilities will not have an effect in response to compliance questioning. ${ }^{152}$ Second, insofar as we are concerned about the actions of state officials, a focus on purpose seems to focus on the wrong issue. Although investigators determined to prosecute may be inclined to pressure suspects, it is not their purpose that leads to unreliable statements, but rather the high-pressure tactics that they employ. ${ }^{153}$ Concerns about reliability, therefore, argue for a distinction between pressurized and low-pressure questioning, not between prosecutorial and non-prosecutorial purpose. ${ }^{154}$

A recognized contributing factor to wrongful convictions is noble cause corruption, "a variant on the rationale that the 'ends justify the means.' That is, that the noble end, the conviction of a person police 'know' is guilty, justifies the use of corrupt means": Dianne L. Martin, "Lessons about Justice from the 'Laboratory' of Wrongful Convictions: Tunnel Vision, the Construction of Guilt and Informer Evidence” (2002) 70 UMKC L. Rev. 847 at 860.

148 Steven Penney, "What's Wrong with Self-Incrimination? The Wayward Path of Self-Incrimination Law in the Post-Charter Era. Part III: Compelled Communications, the Admissibility of Defendants' Previous Testimony, and Inferences from Defendants' Silence” (2003) 48 Crim. L.Q. 474 at 498 [Penney, "Part III"].

149 Steven A. Drizin \& Richard A. Leo, “The Problem of False Confessions in the Post-DNA World” (2004) 82 N.C. L. Rev. 891 . Curiously, the case law discussing the problem of unreliable statements only refers to false statements of innocence: see Fitzpatrick, supra note 5 at para. 44; White, supra note 12 at paras. 61-62; Zwicker, supra note 34 at paras. 30-35. Surely the concern is with unreliable inculpatory statements, not unreliable exculpatory ones.

150 One might ask, however, why the same logic does not lead to routine exclusion of statements in criminal law whenever investigators are trying to gather evidence of guilt, and thus motivated to push suspects into confession. The fact that statements are not statutorily compelled in criminal law seems irrelevant. Statutory compulsion is nothing more than a convenient but unnecessary opportunity to exert pressure. See Christopher Sherrin, "False Confessions and Admissions in Canadian Law" (2005) 30 Queen’s L.J. 601; Gisli H. Gudjonsson, The Psychology of Interrogations and Confessions: A Handbook (Hoboken, N.J.: Wiley, 2003). I am not aware of any study addressing the issue.

153 See Richard A. Leo \& Richard J. Ofshe, "The Consequences of False Confessions: Deprivations of Liberty and Miscarriages of Justice in the Age of Psychological Interrogation” (1998) 88 J. Crim. L. \& Criminology 429. 
One can probably assume that there is some correlation between prosecutorial purpose and high-pressure questioning, but it would be dangerous to assume that the correlation is precise and unwavering. Certainly in criminal enforcement, where investigators are presumed to be pursuing prosecution, the correlation is far from perfect. Empirical studies of police questioning in criminal matters show that many "interrogations" are fairly low-pressure and unsophisticated. ${ }^{155}$ It would also be dangerous to assume that compliance questioning will never be aggressive. Examples certainly exist of confrontational approaches being taken by regulatory officials. ${ }^{156}$ Examples also exist of regulatory officials acting aggressively or abusively in other ways. ${ }^{157}$ But, of course, this leads one to question whether purpose actually distinguishes regulatory and criminal enforcement (as opposed to compliance and prosecutorial strategies in the abstract); if both regulatory and criminal enforcers sometimes pursue their supposedly different purposes in the same way, is the difference in purpose relevant? This brings us to the most significant problem with the purpose argument: its application.

\section{Problems of Application}

Even if all of the theoretical problems are rejected or can be resolved, the purpose argument still would not justify a criminal/regulatory constitutional distinction. The argument incorrectly associates compliance enforcement exclusively with regulatory enforcement. In reality, compliance enforcement is often practised in criminal enforcement, suggesting that compelled statements and warrantless intrusions should sometimes be permissible in the course of such enforcement.

As the law now stands, it is assumed that criminal enforcement follows what Hutter and Hawkins call a sanctioning strategy of enforcement: investigation is conducted not so as to ensure compliance with the criminal law, but to detect and punish criminal offenders. This is not a rule of law, but simply an unquestioned assumption. ${ }^{158} \mathrm{~A}$ similar assumption is not made in connection with regulatory enforcement. The courts allow for the possibility that regulatory officials will sometimes investigate for purposes other than compliance. ${ }^{159}$ The

See e.g. John Baldwin, “Police Interview Techniques: Establishing Truth or Proof?” (1993) 33 Brit. J. Crim. 325; Leo, supra note 131 at 282-84; John Pearse \& Gisli H. Gudjonsson, "Police Interviewing Techniques at Two South London Police Stations” (1996) 3 Psychology, Crime \& Law 63. There are, unfortunately, no Canadian studies on point.

156 See e.g. Schuberg and Treasury Board (Employment and Immigration Canada), [1985] C.P.S.S.R.B No. 210 (QL) (where a customs officer questioned a woman seeking entry into Canada "in an aggressive manner" and with an "accusing” tone); Coleman and Treasury Board (Indian and Northern Affairs Canada), [1988] C.P.S.S.R.B. No. 121 (QL) (where questioning by an auditor for the Department of Indian and Northern Affairs demonstrated a "persistent, relentless, demanding quest by an obviously unsatisfied, unbelieving investigator”); Tanciu and Treasury Board (Veterans Affairs Canada), [1997] C.P.S.S.R.B. No. 25 (QL) (where a doctor working for Veterans Affairs Canada questioned a pension applicant in a manner that suggested scepticism of the application). It is possible that in all these cases the officials were motivated by a prosecutorial rather than a compliance purpose, but the conclusion seems unlikely. Certainly, one must allow for the possibility that compliance questioning can be aggressive. One cannot argue that the presence of aggression automatically means that the regulatory officials must have had a prosecutorial purpose because then the argument becomes tautological and the reference to purpose meaningless — nothing but shorthand for aggressive enforcement.

See e.g. Rollinson v. Canada (1991), 40 F.T.R. 1 at para. 1 (where the actions of customs officers revealed "harassment of, and invocation of illegal proceedings against," a citizen); R. v. Johannson (2006), 200 Man. R. (2d) 183 (Prov. Ct.) (where conservation officers searched inside a family's dresser drawers looking for illegal deer meat). Jarvis, supra note 7. 
initial assumption is that a statement is being compelled or an intrusion made in order to ensure compliance - an assumption that, broadly speaking, will usually, but not always, be legitimate ${ }^{160}$ — but allowance is made for the possibility that the compulsion or intrusion may be for the purpose of collecting evidence for court.

Thus, the purpose argument really only draws a constitutional distinction in one direction. It irrefutably places criminal enforcement in one compartment, to which certain (enhanced) constitutional rights apply, but only presumptively places regulatory enforcement in another compartment, to which different (lesser) constitutional rights apply. Regulatory enforcement can cross the line into the first compartment. Criminal enforcement cannot, or at least is assumed not to, penetrate the second compartment.

In this, the purpose argument reflects an erroneous and outdated understanding of police work. As Wayne LaFave wrote over 40 years ago, "[t]here is a common stereotype of police as ministerial officers whose only function is that of gathering evidence and making an arrest whenever sufficient evidence exist.... A wide gulf ... separates theory and practice.”161 In reality, criminal enforcement officers routinely exercise great discretion in their work, commonly attempting to resolve situations of non-compliance with the criminal law by means other than prosecution. ${ }^{162}$

As noted above, compliance enforcement is characterized by an emphasis on correcting and preventing problems. The preferred tools are persuasion and education. Prosecution is used sparingly. ${ }^{163}$ Much police work adopts the same approach.

Police spend a very small amount of their time dealing with serious crimes. Most of their enforcement time ${ }^{164}$ is spent dealing with relatively minor offences such as drunkenness, assault, impaired driving, vandalism, disorderly conduct, and the like. ${ }^{165}$ Numerous studies have shown that, in dealing with such offences, police (and here we are largely talking about patrol officers) ${ }^{166}$ often adopt a fairly lenient attitude. They exercise their powers of arrest

For examples of regulatory agencies that adopted sanctioning-type strategies of enforcement, see Steven Kelman, "Enforcement of Occupational Safety and Health Regulations: A Comparison of Swedish and American Practices" in Keith Hawkins \& John M. Thomas, eds., Enforcing Regulation (Boston: KluwerNijhoff, 1984) 97; Neal Shover et al., "Regional Variation in Regulatory Law Enforcement: The Surface Mining Control and Reclamation Act of 1977” in Hawkins \& Thomas, 121.

161 Wayne R. LaFave, Arrest: The Decision to Take a Suspect into Custody (Boston: Little, Brown, 1965) at 62 .

162 To quote LaFave, ibid. at 61, again, "[d]ecisions not to arrest because of the nature of the offense, the circumstances of its commission, or some other factor are made routinely."

163 There are, of course, variations in how compliance officers pursue their task, but the general outline of the approach remains the same: see especially Hutter, Reasonable Arm, supra note 90, c. 5-6.

164 I refer to "enforcement time" because much police time is spent performing service duties that are unrelated to the enforcement of any law (such as aiding physically or mentally ill persons, finding lost children, etc.): see e.g. Tommy Landau, "Policing and security in four remote aboriginal communities: A challenge to coercive models of police work" (1996) 38 Can. J. Crim. 1; Richard V. Ericson, Reproducing Order: A Study of Police Patrol Work (Toronto: University of Toronto Press, 1982) at 5-6. James Q. Wilson, Varieties of Police Behavior: The Management of Law \& Order in Eight Communities (Cambridge: Harvard University Press, 1968) at 6; Ericson, ibid. at 206.

166 This does not minimize the significance of the point. Patrol normally makes up the largest part of police operations: Gordon P. Whitaker, “What is Patrol Work?” in Gary W. Cordner, Larry K. Gaines \& Victor E. Kappeler, eds., Police Operations: Analysis and Evaluation (Cincinnati: Anderson Publishing, 1996) 55. 
infrequently. ${ }^{167}$ More often, they employ alternative tactics. ${ }^{168}$ Arrests are sometimes made, but commonly because alternative responses have failed, or for other reasons that only incidentally relate to the fact that the law has been violated.

The classic study in this regard is James Wilson's 1968 study of police behaviour in eight communities in the U.S. ${ }^{169}$ He determined that the patrol officer's role is defined more by her responsibility for maintaining order than for enforcing the law. ${ }^{170}$ Although the officer may use the law to make an arrest, just as often she will respond to a crime by doing something else, such as issuing a warning, delivering a lecture, separating disputants, pacifying aggrieved parties, encouraging informal restitution or civil action — or just ignoring the offence. The law is but one resource available to deal with disorder, neither the only nor even the most important one. In Wilson's words, the patrol officer

approaches incidents that threaten order not in terms of enforcing the law but in terms of "handling the situation." The officer is expected, by colleagues as well as superiors, to "handle his beat." This means keeping things under control so that there are no complaints that he is doing nothing or that he is doing too much. $^{171}$

For most officers, considerations of utility equal or exceed in importance the literal dictates of the law, especially when it comes to more common, less serious offences. The officer asks herself whether anyone has been hurt or deprived, whether the offender is likely to re-offend, whether an arrest will improve the situation or only make matters worse, etc. "The decision to arrest, or to intervene in any other way, results from a comparison, different perhaps for each officer, of the net gain and loss to the suspect, the neighborhood, and the officer himself of various courses of action." ${ }^{172}$ Arrest is simply one option, often employed only if order cannot be restored or respect for authority elicited in any other way.

The patrol officer's approach to her job, as described by Wilson, is remarkably comparable to the regulatory officer's approach to her job as described by numerous observers. ${ }^{173}$ Regulatory officers similarly tend to be interested in "handling the situation" as much as or more than enforcing the law. They also tend to respond informally to illegal action. They also are driven by considerations of utility, asking themselves whether damage

See Donald J. Black, “The Social Organization of Arrest” (1971) 23 Stan. L. Rev. 1087 at 1106 [Black, "Social Organization”]; Egon Bittner, “The Police on Skid-Row: A Study of Peace Keeping” (1967) 32 American Sociological Review 699 at 702.

Graphic evidence of this is found in the recent large-scale study by William Terrill \& Eugene A. Paoline III, "Nonarrest Decision Making in Police-Citizen Encounters" (2007) 10 Police Quarterly 308. The researchers examined thousands of police-suspect encounters and found that officers failed to arrest in almost 90 percent of cases (at 317). Even in the cases where the inculpatory evidence was strongest, officers only arrested about 25 percent of the (apparent) offenders. Supra note 165.

Wilson, ibid. at 16, defined order as "the absence of disorder," and disorder as "behavior that either disturbs or threatens to disturb the public peace or that involves face-to-face conflict.”

Ibid. at 31 [emphasis in original; footnotes omitted].

Ibid. at 84.

See Hawkins, Environment and Enforcement, supra note 91; Hawkins, Law as Last Resort, supra note 138; Hutter, Reasonable Arm, supra note 90; Bridget M. Hutter, Compliance: Regulation and Environment (Oxford: Clarendon Press, 1997) [Hutter, Compliance]; Genevra Richardson, Anthony Ogus \& Paul Burrows, Policing Pollution: A Study of Regulation and Enforcement (Oxford: Clarendon Press, 1982). 
has occurred, whether recidivism is likely (or at least can be minimized), and whether prosecution will help more than hurt.

This is not to say that the patrol officer's approach is necessarily identical to the regulatory officer's; the latter, for example, can adopt an especially conciliatory attitude towards rulebreaking. But the similarities are present. Most importantly, those similarities reveal and reflect the fact that police officers sometimes adopt a compliance strategy of enforcement. ${ }^{174}$

Exactly how often police officers adopt this strategy is hard to say. Wilson himself noted that some police departments and officers adopted a more legalistic (that is, prosecutorial) style of enforcement. ${ }^{175}$ Clearly, the police will also employ a compliance strategy less often when dealing with serious offences that cause serious harm. But the point remains that, for purposes of constitutional interpretation, it is inappropriate and just plain inaccurate to lump all criminal enforcement into a single sanctioning compartment. Police sometimes (and apparently with some frequency) employ a compliance strategy of enforcement.

The skeptical reader may object that Wilson's is but a single study that was completed over 40 years ago in a different country. That is true, but Wilson's findings have been validated repeatedly over the years on both sides of the border (and beyond) ${ }^{176}$ The classic Canadian study of police patrol work was completed by Richard Ericson in the 1980s. ${ }^{177} \mathrm{He}$ concluded that patrol work is not primarily about law enforcement, but about reproducing the existing order: ${ }^{178}$

[I]n dealing with any particular situation the patrol officer decides what, if anything, is out of order and then employs the various tools at his disposal to reconstruct order. If he is seeking compliance from a citizen, he can rely upon the aura of the general authority of his office; his procedural legal powers to detain, search, and use physical force; his substantive legal powers to charge; and various manipulative strategies that form part of the 'recipe' knowledge of his craft. In short, he 'negotiates order,' variously employing strategies of coercion, manipulation, and negotiation. ${ }^{179}$

When confronted with evidence of illegal conduct, patrol officers observed by Ericson commonly responded with something other than arrest and prosecution. They admonished, cautioned, and threatened suspects. They counseled complainants about alternative remedies

This fact has long been recognized by those who study enforcement behaviour. As Bridget Hutter has noted, "[w]hile studies generally associate regulatory enforcement with the accommodative style and the sanctioning style with the police, it was always emphasized [in the academic literature] that in reality all enforcement agencies would use both styles, albeit with differing levels of commitment. This is because the two broad strategies are analytical models or ideal types of enforcement strategy": Hutter, Compliance, ibid. at 15. Supra note 165 , c. 6.

176 See e.g. Terrill \& Paoline, supra note 168; Richard E. Skyes, James C. Fox \& John P. Clark, “A SocioLegal Theory of Police Discretion” in Abraham S. Blumberg \& Arthur Niederhoffer, eds., The Ambivalent Force: Perspective on the Police, 2d ed. (Hinsdale, Ill.: Dryden Press, 1976) 171; Whitaker, supra note 166 at 66-67; Douglas A. Smith \& Christy A. Visher, "Street-Level Justice: Situational Determinants of Police Arrest Decisions” (1981) 29 Social Problems 167; Wayne R. LaFave, “The Police and Nonenforcement of the Law - Part II" [1962] Wis. L. Rev. 179. Supra note 164.

178 To Ericson, ibid. at 7, reproducing order means transforming "troublesome, fragile situations back into a normal or efficient state whereby the ranks in society are preserved" and "disciplining, refining, and improving the population.” Ibid. at 9 [footnotes and citations omitted]. 
(for example, informal compensation from the culprit, non-criminal help for interpersonal disputes, civil suits, etc.). They negotiated settlements to disputes, sometimes by redefining the situation in a way that no longer made it a police matter. They certainly did not invariably apply the law to the facts of the case and initiate formal proceedings whenever the relevant legal criteria were satisfied. In the reproduction of order,

[t]he criminal law becomes a 'residual resource' used when other methods of resolving a situation are unavailable or have been tried and are unsuccessful. Similar to the way citizens use the police, police use the law according to what other forms of social control are available and can be used effectively. For the patrol police, this is particularly the case in interpersonal disputes and problems of public order and decorum. When all else fails or is deemed likely to fail, the officer decides he must remove one party in the conflict from the situation, and consequently he arrests someone. A specific infraction with a clearly applicable law does not determine the arrest, but rather the law is used to make the arrest to handle the situation. ${ }^{180}$

The findings of Wilson and Ericson regarding general patrol work have been replicated in studies of enforcement of the criminal law in more specific communities and situations, and in relation to more specific offences and citizen groups. Probably most well known in this regard are studies showing that police often exercise discretion not to arrest or prosecute when dealing with young persons. A recent study of 95 police departments in Canada, for example, found that a "great majority" of officers "frequently" use informal action with youth believed to be in breach of the criminal law. ${ }^{181}$ The exercise of discretion is not reserved for young people, however. Frequent use of non-prosecutorial responses to crime has been documented in police enforcement on "skid-row," ${ }^{\text {"182 }}$ in Aboriginal communities, ${ }^{183}$ in labour disruptions, ${ }^{184}$ in motor vehicle enforcement, ${ }^{185}$ in low-level drug enforcement, ${ }^{186}$

Ibid. at 14 [citations omitted].

Peter J. Carrington \& Jennifer L. Schulenberg, Police Discretion With Young Offenders (Ottawa: Department of Justice Canada, 2003) at iii (see generally, c. 2). Informal action included warnings, involving parents, arresting and later releasing without charge, and arresting and referring to pre-charge alternative measures. See also Wilson, supra note 165 at 145-46; Ericson, ibid. at 154-55; John Liederbach, "Controlling Suburban and Small-Town Hoods: An Examination of Police Encounters with Juveniles” (2007) 5 Youth Violence \& Juvenile Justice 107.

Bittner, supra note 167. At 710 [footnote omitted], Bittner commented:

In the majority of minor arrest cases ... the criteria the law specifies are met. But it is the rare exception that the law is invoked merely because the specifications of the law are met. That is, compliance with the law is merely the outward appearance of an intervention that is actually based on altogether different considerations. Thus, it could be said that patrolmen do not really enforce the law, even when they do invoke it, but merely use it as a resource to solve certain pressing practical problems in keeping the peace.... The reduced relevance of culpability in peace keeping practice on skid-row is not readily visible.... It becomes partly visible when one views the treatment of persons who are not arrested even though all the legal grounds for an arrest are present. Whenever such persons are encountered and can be induced to leave, or taken to some shelter, or remanded to someone's care, then patrolmen feel, or at least maintain, that an arrest would serve no useful purpose. That is, whenever there exist means for controlling the troublesome aspects of some person's presence in some way alternative to an arrest, such means are preferentially employed, provided, of course, that the case at hand involves only a minor offence. Landau, supra note 164.

Alan Hall \& Willem De Lint, “Policing Labour in Canada” (2003) 13 Policing \& Society 219.

Allan R. Meyers, Timothy Heeren \& Ralph Hingson, "Discretionary Leniency in Police Enforcement of Laws Against Drinking and Driving: Two Examples from the State of Maine, USA" (1989) 17 Journal of Criminal Justice 179; David H. Bayley, "The Tactical Choices of Police Patrol Officers" (1986) 14 Journal of Criminal Justice 329.

Nicholas Dorn \& Karim Murji, “Low Level Drug Enforcement” (1992) 20 Int’l J. Soc. L. 159; Hamish Warburton, Tiggey May \& Mike Hough, "Looking the Other Way: The Impact of Reclassifying Cannabis on Police Warnings, Arrests and Informal Action in England and Wales” (2005) 45 Brit. J. Crim. 113. 
in connection with the mentally ill, ${ }^{187}$ in relation to interpersonal disputes, ${ }^{188}$ etc. The police are clearly approaching a wide variety of situations with something very different than a single-minded desire to arrest and prosecute. Sanctioning strategies are being employed, but not to the exclusion of compliance strategies. Indeed, in some circumstances compliance strategies are dominant.

Police behaviour in this regard does not simply arise when, and because, the evidence is insufficient to justify an arrest. Although the relevant studies do not always confine their observations to situations where an arrest is possible, ${ }^{189}$ they clearly include many such situations in their data sets. As one author emphasized, “even when the evidence against a suspect is very strong, the police frequently take action short of arrest. Evidence alone ... is a necessary but not a sufficient basis for predicting invocation of the law."190

Compliance enforcement of criminal law does raise right to privacy and right against selfincrimination issues. One might be tempted to assume that a non-prosecutorial strategy is only employed in connection with trivial offences where no interrogations or searches are undertaken. That assumption would be false. First of all, there is evidence that compliance enforcement is sometimes employed in connection with serious crimes. ${ }^{191}$ More importantly, it is clear that police routinely question and search individuals suspected of committing less serious crimes. ${ }^{192}$ Questioning suspects is a basic part of all police work. It is how police seek to confirm or refute suspicions, whether generated by activity they observe or complaints they receive. That such questioning occurs in the context of compliance enforcement cannot seriously be doubted. ${ }^{193}$ What may be slightly less obvious, but no less true, is that police also conduct searches in the context of compliance enforcement. They search potential troublemakers for weapons to prevent dangerous situations from developing. ${ }^{194}$ They search drunks for alcohol to minimize public nuisances. ${ }^{195}$ They search gamblers for betting cards

Thomas M. Green, "Police as Frontline Mental Health Workers: The Decision to Arrest or Refer to Mental Health Agencies” (1997) 20 Int'l J.L. \& Psychiatry 469.

188 See Bayley, supra note 185; Douglas A. Smith, "Police Response to Interpersonal Violence: Defining the Parameters of Legal Control" (1987) 65 Social Forces 767; Donald Black, The Manners and Customs of the Police (New York: Academic Press, 1980), c. 5 [Black, Manners and Customs]; Lynette Feder, "Police Handling of Domestic and Nondomestic Assault Calls: Is There a Case for Discrimination?” (1998) 44 Crime \& Delinquency 335. The police, in fact, were notorious for responding to instances of domestic violence other than by arrest and prosecution: see e.g. Ericson, supra note 164 at 113-14. It is for that reason that mandatory arrest policies in such cases were instituted.

Some do: see Terrill \& Paoline, supra note 168; Sykes, Fox \& Clark, supra note 176.

Black, "Social Organization,” supra note 167 at 1107.

See e.g. ibid. at 1093, who found that police in his study arrested only 58 percent of felony suspects even though they had probable cause to arrest in nearly every case. See also Smith \& Visher, supra note 176 at 170; John P. Crank, "Police Style and Legally Serious Crime: A Contextual Analysis of Municipal Police Departments” (1992) 20 Journal of Criminal Justice 401; Smith, supra note 188; Black, Manners and Customs, supra note 188 at 180-86.

Indeed, there is evidence that police sometimes resort to interrogations and searches as a means of securing compliance. Most explicit in this regard is the study by Liederbach, supra note 181 at 116 , who documented how the police, as a means of exercising informal control in the absence of arrest, sometimes interrogated juveniles and/or searched their persons or property.

If any evidence is needed, Tiffany, McIntyre \& Rotenberg give the example of questioning a person who seems out of place in a neighbourhood and thus who might be looking for a prostitute (in order to scare him away): Lawrence P. Tiffany, Donald M. McIntyre Jr. \& Daniel L. Rotenberg, Detection of Crime: Stopping and Questioning, Search and Seizure, Encouragement and Entrapment, ed. by Frank J. Remington (Boston: Little, Brown, 1967) at 12. See also Bittner, supra note 167 at 708.

Tiffany, McIntyre \& Rotenberg, ibid. at 13.

Ibid. at 14. 
to harass them out of the neighbourhood. ${ }^{196}$ They search potential users for narcotics. ${ }^{197}$ The list goes on. ${ }^{198}$ Unlike regulatory authorities, the police may not have the legal authority to conduct such searches, but when the goal is not prosecution the legal limitations on the power to search do not always act as a constraint. ${ }^{199}$

If purpose matters to constitutional interpretation, it should matter in both regulatory and criminal enforcement. Neither employs a particular enforcement strategy exclusively. Both employ a compliance strategy in at least some cases. A portion of those cases will nonetheless end up before the courts. When they do, purpose affords no reason for the courts to treat them differently. If a prosecutorial purpose justifies enhanced rights in a criminal context, it should in a regulatory context. Similarly, if a non-prosecutorial purpose justifies lesser rights in a regulatory context, it should also in a criminal context. The relevance of purpose is a function of the facts of the case - any case. It does not support a categorical distinction between regulatory and criminal cases.

\section{Conclusion}

Canadian constitutional law currently draws a distinction between regulatory and criminal investigations. It is generally only in the latter that people have Charter rights not to be compelled to provide statements that can later be used against them and not to be subjected to warrantless intrusions or demands for production. This distinction has often been justified by reference to investigative purpose. It is alleged that there are different purposes behind regulatory and criminal investigations. The former are intended to ensure compliance with the law. The latter are intended to gather evidence for prosecution. It is only in the latter, therefore, that protection against statutory compelled statements and warrantless intrusions is necessary as a means of safeguarding the principle against self-incrimination.

In this article I have challenged the validity of the justification based on purpose. It suffers from a variety of significant flaws. Perhaps most importantly, it incorrectly assumes that criminal enforcement is never undertaken in a manner similar to regulatory enforcement; namely, with a view to ensuring compliance with the law. As such, it does not recognize that, by its own dictates, it suggests that there should not be a constitutional distinction drawn on criminal/regulatory lines. But even if the justification based on purpose was taken to its logical conclusion there is still reason to believe that it should not be accepted. Focusing on investigatory purpose is irrelevant to the interests protected by the right to privacy, offers no real protection against the admission of unreliable evidence, relies on a mischaracterization

Joseph Goldstein, “Police Discretion Not To Invoke The Criminal Process: Low-Visibility Decisions in the Administration of Justice” (1960) 69 Yale L.J. 543 at 580.

Warburton, May \& Hough, supra note 186 at 119, 122.

Bittner, supra note 167, for example, told the story of a police officer, in the regular course of his patrol, "unceremoniously" entering "the room of a man he had never seen before.” The man "gave no indication that he regarded the officer's entry and questions as anything but part of life as usual” (at 709). Bittner added at 708 :

Officers are quite aware that the directness of their approach and the demands they make are difficult to reconcile with the doctrines of civil liberties, but they maintain that they are in accord with the general freedom of access that persons living on skid-row normally grant one another. That is, they believe that the imposition of personalized and far-reaching control is in tune with standard expectancies. In terms of these expectancies, people are not so much denied the right to privacy as they are seen as not having any privacy.

See Tiffany, McIntyre \& Rotenberg, supra note 193 at 183-87. 
of the true nature of regulatory enforcement, and undermines the very principle it is said to protect: the principle against self-incrimination. It results in a situation where it matters not that an accused is conscripted against herself, but only that the state did not, at some earlier point in time, mean to conscript the accused against herself. That simply cannot be the important consideration.

None of this proves that the constitutional distinction between regulatory and criminal investigations cannot be defended. Other justifications for the distinction have been advanced. Undermining what is arguably the primary justification, however, at least begs the question of whether the distinction can be justified. I doubt that it can. But, whether or not I am right, the analysis in this article should make one thing abundantly clear: we need to subject to much greater scrutiny the justifications for why the Charter has been interpreted so differently in the criminal and regulatory spheres. We may be surprised by what we find. 